\title{
Stonehenge and Avebury: Megalithic shadow casting at the solstices at sunrise
}

\author{
G. Terence Meaden \\ Oxford University Department of Continuing Education (Archaeology), Kellogg College, Oxford University, 62 \\ Banbury Road, Oxford, UK. Email: terencemeaden01@gmail.com
}

\begin{abstract}
:
The paper examines how specific megaliths at Stonehenge and Avebury were positioned relative to others and to particular sunrises such as to produce watchable effects arising from solar movement and resulting lithic shadows. At Stonehenge and environs numerous research expeditions (exceeding 120 that started in 1981) combined with accurate compass analysis, photography and studies of the best plans of the sarsen-stone and bluestone phases have led to explanations for apparent anomalies of stone positioning that have not been clarified before.

Firstly, at the summer solstice in the Late Neolithic the Altar Stone was illuminated by sunshine for the first three or four minutes of the day, following which the shadow of the round-topped Heel Stone was cast into the middle of Stonehenge to reach the Altar Stone. This circumstance continues to be witnessed today. It is a consequence of the Heel Stone being deliberately offset from the Stonehenge axis of symmetry. Again, there is the offset positioning of the anomalous half-height, halfwidth, Stone 11 that disrupts the otherwise regular arc of the lintelled sarsen circle. It is also a fact that the Altar Stone, although on the midsummer sunrise axis and bisected by it, does not lie perpendicular to the monument's axis but is instead angled lengthways in the direction of the winter solstice sunrise. The same is true of the orientation of the Great Trilithon (as recently discussed by T. Daw). This suggests that the Altar Stone and the Great Trilithon were deliberately positioned this way in order to respect and emphasise an older arrangement in which a midwinter sunrise megalithic setting had been important. Such an arrangement involving the winter solstice sunrise still exists because the shadow of the short round-topped Stone 11 at sunrise appears aimed at the rhyolite ignimbrite Bluestones 40 and 38 - both of which are damaged, fallen and possibly parts of a single original. In similar manner the site of Hole $\mathrm{G}$ could indicate the former position of an ancestral stone with regard to equinoctial sunrises. Thus, these shadow-casting experiences for sunrise at Stonehenge may have affinities with the proven stone-to-stone casting of shadows for the same significant calendar dates at the carefully examined Drombeg Stone Circle. At Avebury the stones of the Cove in the northern circle together with Avebury's Stone F harmonize likewise at the summer solstice sunrise. Two surviving megaliths in Avebury's southern circle behave similarly. It is discussed whether an explanation in terms of the ancient worldview of the hieros gamos between Sky and Earth may be appropriate for Stonehenge and Avebury as it could also be at Drombeg.
\end{abstract}

Keywords: altar stone; Avebury; Heel Stone; hieros gamos; shadow casting; Stonehenge; summer solstice sunrise; winter solstice sunrise; winter solstice sunset

Published by the School of History, Classics and Archaeology, University of Edinburgh ISSN: 2055-0472. URL: http://journals.ed.ac.uk/lithicstudies/

This work is licensed under a Creative Commons Attribution 2.5 UK: Scotland License. 


\section{Introduction}

Stonehenge in southern England is one of the world's most remarkable and puzzling monuments from the Neolithic and Bronze Age, and is all the more attractive because of its mysteries.

It is a masterpiece of planning and engineering achievement that dates from British Neolithic prehistory and for which the detailed design reasoning is unknown since the loss of the knowledge of the people who built and used it.

In the present research it is the period beginning with the era of the shaped sarsen stones - about $2550 \mathrm{BCE}$ - that attracts initial attention. The biggest stones, in the central area of the re-planned monument, were raised first, and the outer ring of standing stones with lintels followed. In its sarsen form Stonehenge continued in use for about a thousand years before abandonment, after which, in disuse, it suffered from a total lack of maintenance. Stones fell, and visitors wreaked damage by striking off pieces for souvenirs or for what they were led to believe were medicinal or healing purposes (Chippindale 1983: 44, 159; Darvill \& Wainwright 2009). And now Stonehenge - which is only minimally repaired - instead attracts the attention of the world for its tumbled beauty and continuing enigma.

What then did it mean, the plan of the 26th century BCE that was devised by a visionary architect of unknown name? This is where the secrets of Stonehenge lie - in the design plan and its relation to the positioning of specific stones surviving from an earlier era of the monument. In assessing these problems it is shown how helpful the research undertaken at Drombeg proves to be, at which stone circle so many perimeter stones survive unharmed that sunrise shadow casting is readily tested on site for all eight traditional agricultural festival days (Meaden 2017).

Only a few studies have earlier examined effects of sunlight and shade caused by standing stones. In October 1985 the author began the present Stonehenge research on the concept of shadow casting at the summer solstice. The first research photographs of a shadow cast by the Heel Stone at Stonehenge in the week of the summer solstice were taken in 1986, and the first published solstice-week photographs (dated 1987 and 1989) followed in 1992 (Meaden 1992: plates 13, 14,15; Meaden 1997).

Meanwhile, unknown to the author, Prendergast (1991: fig. 5) reported his M.Sc. study of winter solstice shadow-casting at Newgrange. Bradley (1989), rather differently, discussed matters of darkness and shade in the interiors of megalithic-chambered tombs using examples from the south of Brittany. Pásztor (2000) and Pásztor et al. (2011) considered aspects of light and shade within Stonehenge at the summer solstice. Pritchard (2016) has discovered examples of shadow casting in Wales involving stone pairs between one standing stone and the base of its neighbour. The principal reported events involve the winter or summer solstices or the equinoxes.

As with Ruggles (1997) when writing of Stonehenge, Pásztor et al. (2011: 6) remark that attempts to explain the orientation towards the midsummer sunrise is often done from the point of view of observers inside the monument looking outwards along the axis, and yet the small space in the interior allows few observers to participate in this. Pásztor then approached the problem differently "through the experiential act of virtual reality reconstructions of the materiality of a prehistoric monument in its terrestrial and celestial location". Results were interesting as to the spatially changing effects of brightness due to sunlight across the entire interior during the subsequent hour or so. The present author's approach differs by considering what watchers would see from outside when facing the monument and standing in the region of the Heel Stone as the sun rose. By the nature of the Heel Stone's huge shadow moving across the ground with its point penetrating the monument to reach the Altar Stone and then withdrawing and shortening, many dozens of people, if not hundreds, could see this 
happening. It would be an experience and celebration for an entire community - not just for a few priests standing near the Altar Stone.

Neolithic Avebury, also in Wiltshire, is considered too in a joint effort of trying to learn something of the intentions of the planners of both monuments

\section{Methodology}

For Stonehenge the most useful survey plans are those in Cleal et al. (1995: 28, 234, 344 and loose insert plans). For Avebury the plan that serves best was published by Smith (1965: 205, fig. 70) because it makes use of Alexander Keiller's surveys and excavations. In the preceding paper of the present volume (Meaden 2017) the stone circle at Drombeg in Ireland was analyzed in such detail that the principles of the basic discoveries (shadow casting and stone-to-stone positioning) can now be tested with respect to the Wiltshire monuments.

Attention is directed to features of Stonehenge that appear anomalous insofar as certain stones appear out of alignment, but for which there would have been good reason at the time of planning in the third millennium.

For instance, (1) the huge stone standing outside the monument - the Heel Stone - is slightly off line as regards the rising point of the sun at the summer solstice relative to the symmetry of the main monument. (2) There is the Slaughter Stone in which the puzzle relates to the reason for its positioning before it fell or was felled. (3) Thirdly, why is a stone of the main sarsen circle - Stone 11 - much shorter and less wide than the others, being also round topped and never intended to be lintel-bearing, while standing awkwardly just off the circumference of the linteled sarsen circle? (4) Fourthly, at the focus of the monument, was the Altar Stone standing or did it lie recumbent?

At Avebury similar questions as to the precision of stone positioning arise too.

The answers presented here have reference to the choice of stones by shape and positioning. They result from consulting the best plans, and making many site visits checking the positions of crucial stones in combination with high accuracy compass measurements.

For the latter a military compass marked at one-degree intervals that can be read through its prismatic viewfinder to the nearest half-degree was used. Finally, quality photography was undertaken, initially with a Minolta single lens reflex AF 7000 film camera and latterly by a digital SLR Sony Alpha 290 at numerous sunrises that include the summer and winter solstices and sunset at the winter solstice.

\section{Results for sunrise light and shade effects at Stonehenge at the summer solstice}

Important stones at Stonehenge are the externally located Heel Stone (Figure 1) and the internally positioned focal stone called the Altar Stone.

Other key stones are the pairs numbered as Stones 1 and 30 that together with the midpoint of the Altar Stone define the axis of the monument. At the same time the Stonehenge axis is the bisector of the nearest section of the long ditch-and-bank avenue. Both the axis and the Avenue correspond with the azimuth of midsummer sunrise as it was 4500 years ago. Figure 2 is a map of the monument.

On the mornings of the week of Neolithic summer solstice, solar phenomena begin when the light of the rising sun streams past the externally located Heel Stone to enter the central portals (Figure 2) and reach the Altar Stone which, as now in the final arrangement of the stones of Stonehenge, lay recumbent. After a few minutes the moving sun - as viewed from the centre of the monument - becomes eclipsed by the standing Heel Stone (Figure 3).

During the eclipse period ( 3 to 4 minutes long) the moving sun throws the phallic shadow of the Heel Stone into the Stonehenge monument (Figure 4). There, on the ground at the focus of the monument, the shadow encounters the recumbent Altar Stone (or in a still 
earlier age a possibly standing Altar Stone) (Meaden 1997; 2012a: 76). This union between rising sun and recumbent Altar Stone is an event timed for midsummer week, and in clear sky conditions has taken place every year of the last 4500 years. Note how this compares with events taking place at the summer solstice in Drombeg (Meaden 2017). It was similar at Avebury (compare with Sections 4.5 and 4.6 below).

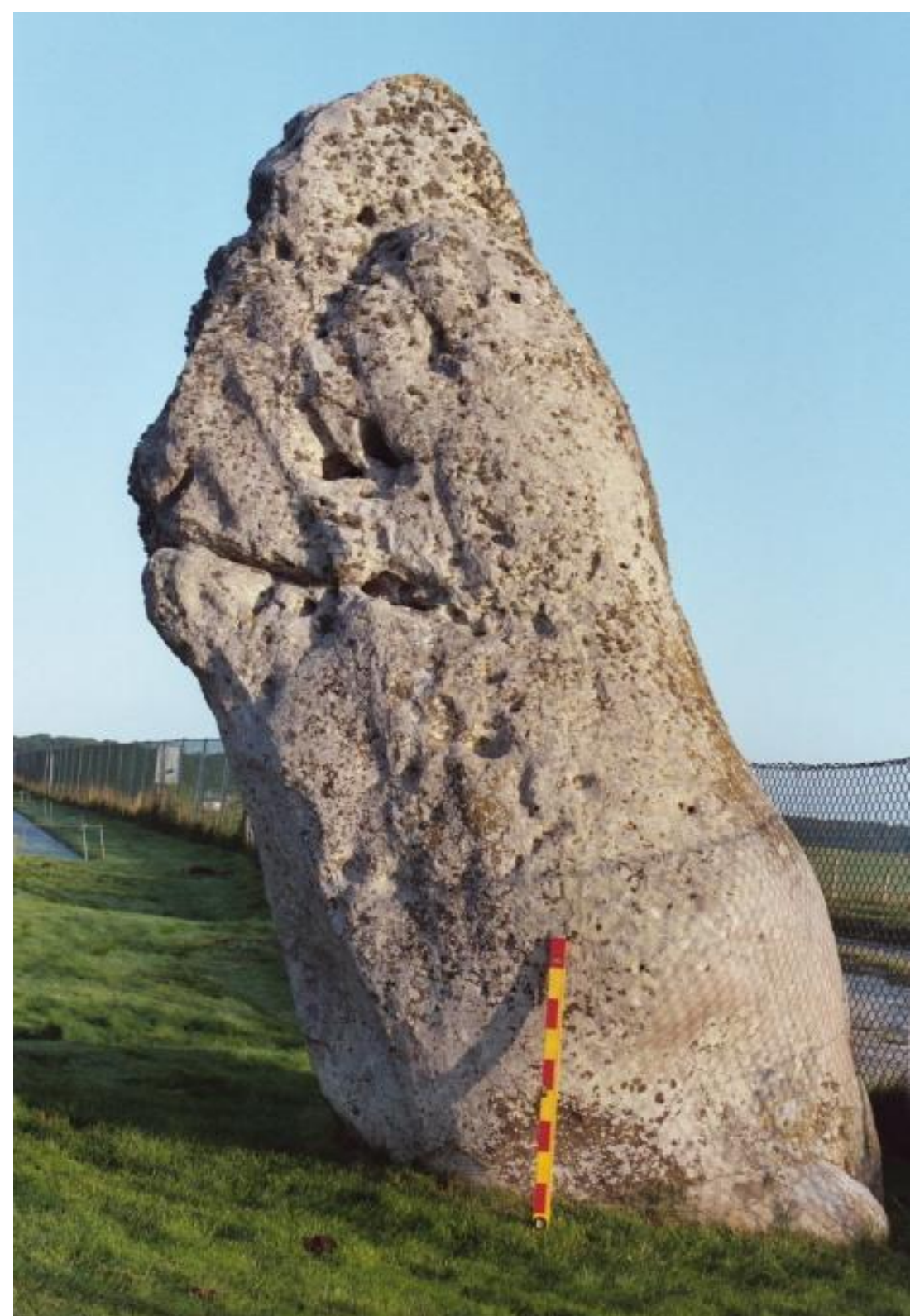

Figure 1. The Heel Stone stands outside the monument beyond the henge ditch and bank. (Photograph by the author.)

The Altar Stone, being a rich mica-filled megalith, would sparkle in the sunshine if freshly scraped or wetted. Midsummer week is the supreme time of year when the light of the rising sun can reach it. By contrast, in the week of midwinter at sunset only a narrow beam of sunlight can reach a small part of the back of the Altar Stone, having passed between perimeter Stones 15 and 16 and the narrow gap between the stones of the Great Trilithon 55 and 56 (Figure 2).

Note that Atkinson (1979: 211-212) reported that one end of the Altar Stone had been obliquely bevelled. This suggests that, although now lying flat (Cleal et al. 1995: 29; Daw 
2015) and therefore not in need of a stone-hole if it was expressly positioned to be prone, then in some period of the monument's history earlier than the final phase, the stone may have stood upright (Atkinson 1979: 211-212). Cleal et al. 1995: 188) consider a possible stone hole for it.

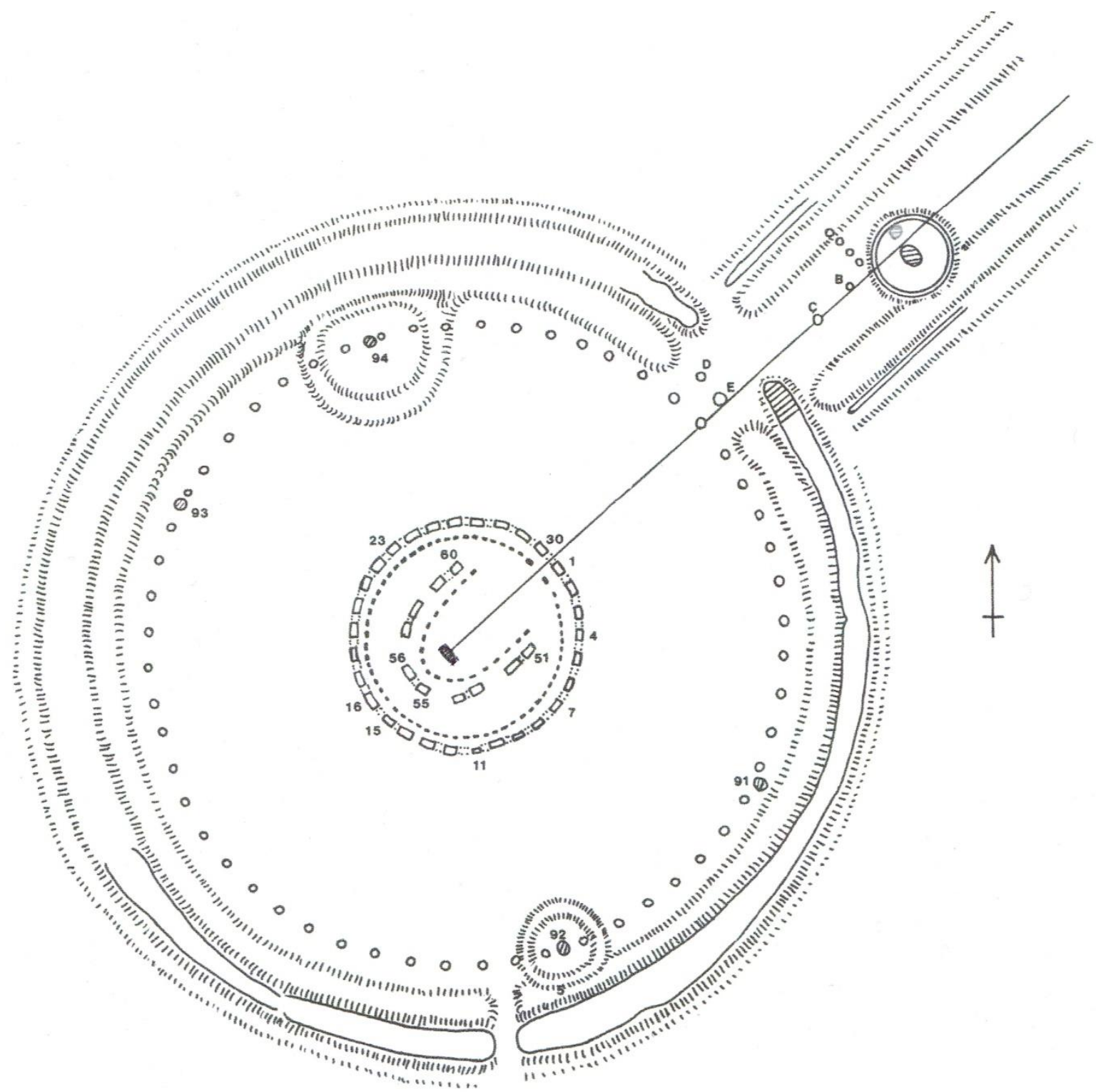

Figure 2. Plan of Stonehenge as it may have been in its final phase if construction had been fully completed. Note how the stone pair numbered 30 and 1 together with the midpoint of the recumbent Altar Stone define the axis of the monument - as does the bisector of the Avenue on the final approach to Stonehenge. Yet, the Heel Stone which is 80 metres from the centre of the monument is slightly offset from the Stonehenge axis. Also note that the Heel Stone has a ring ditch around it that cuts an earlier, therefore older, stone hole (Pitts 1981: fig. 1; Cleal et al. 1995: fig. 79) which is farther from the monument than is the Heel Stone. This older stone hole (attributed to a missing Stone 97) is sketched lightly on this plan on the inside edge of the Heel Stone circle. (Author's drawing based on published plans including Stone (1924: plate 3), excavator Hawley (1928: plate 23), Atkinson (1956: fig. 8, facing p. 204) and Pitts (1982: 77)).

Also note that 4500 years ago, because of subsequent changes in Earth's ecliptic due to the precession of the equinoxes, the sun rose farther north than it does now by the width of two solar diameters, or one degree of arc. Figure 3 partly reflects this. 


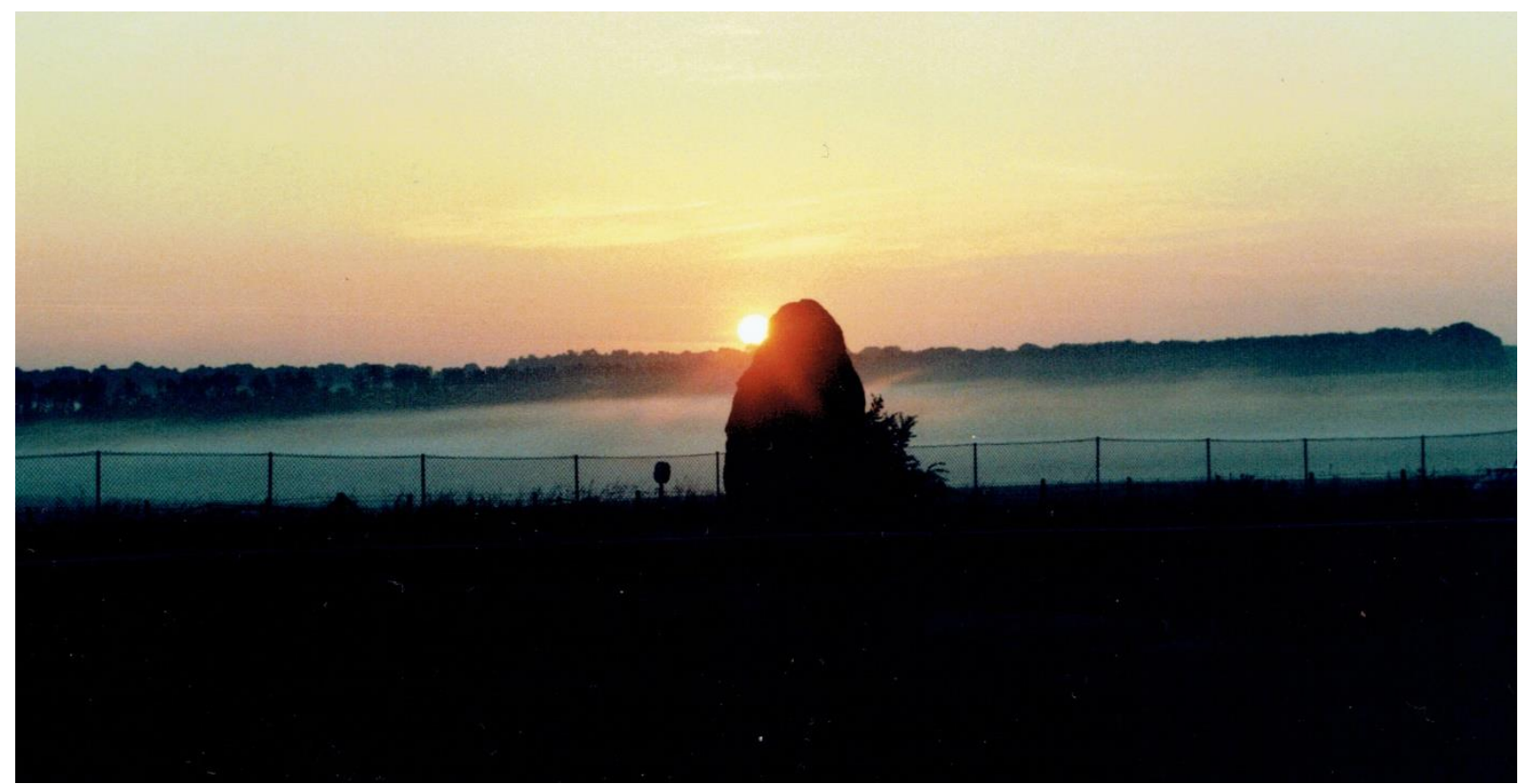

Figure 3. Reconstruction of how the Neolithic rising sun appeared when observed from ground level on the Stonehenge axis in the middle of the monument. The Heel Stone stands 4.7 metres high in its present leaning state. If restored to the vertical, it would stand nearer $5.2 \mathrm{~m}$ high (Atkinson 1978: 51-52). Photograph by the author.

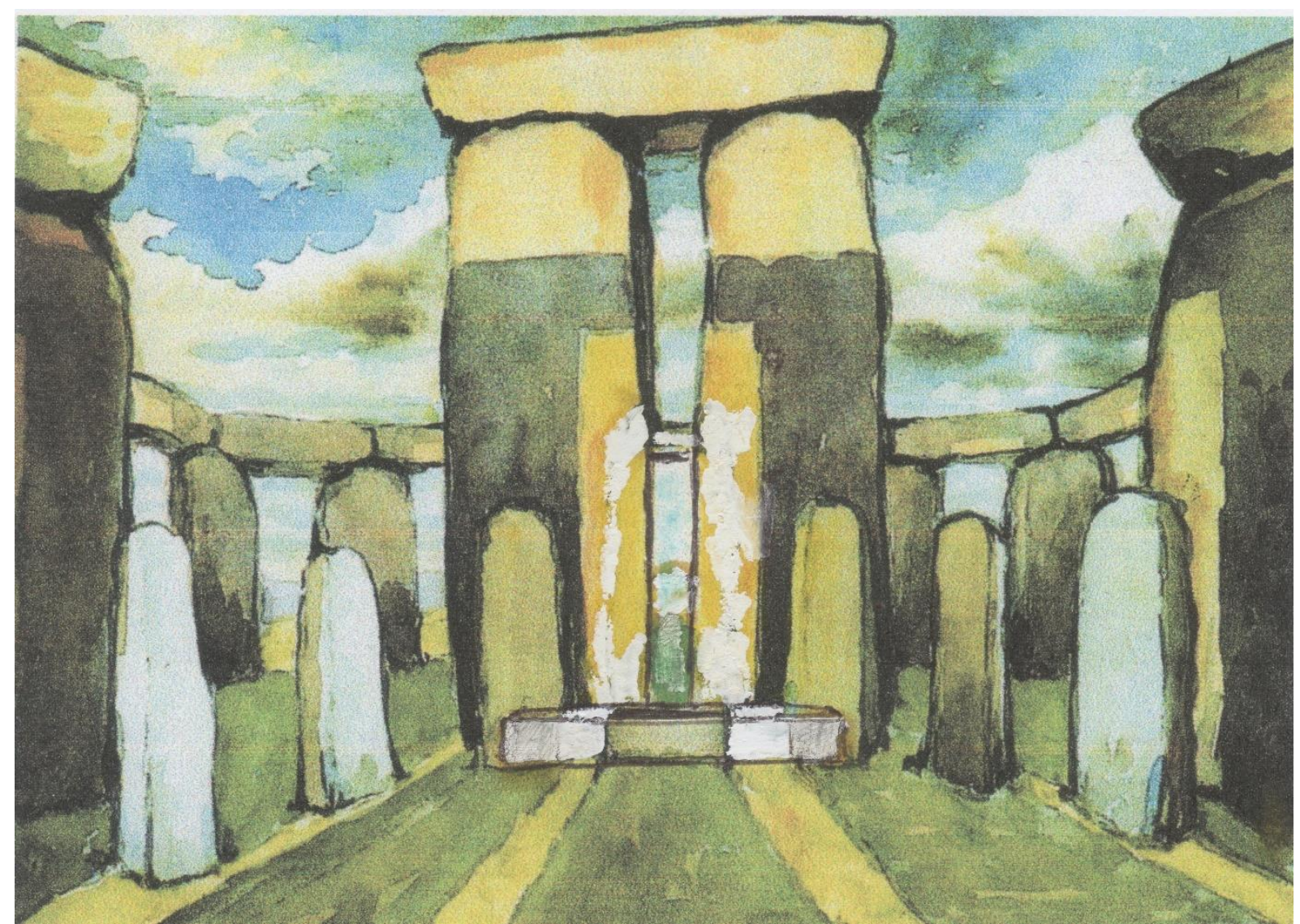

Figure 4. Schematic illustration of how Stonehenge was intended to function in its final phase. The Heel Stone shadow reaches the recumbent Altar Stone - as it still does every midsummer week in clear sunrise conditions. Note, too, that both the Great Trilithon and the Altar Stone are skewed slightly through 10 degrees because that is how the Altar Stone and the standing Great Trilithon Stone 56 are now (see Section 4.1). (Painted by Maureen Oliver with publishing permission.) 
The view that the expectant community had, waiting outside the monument under conditions of a bright rising sun, is demonstrated by Figure 5. Many dozens of spectators could witness and appreciate the phenomenon even if weakened by veiled sunshine.

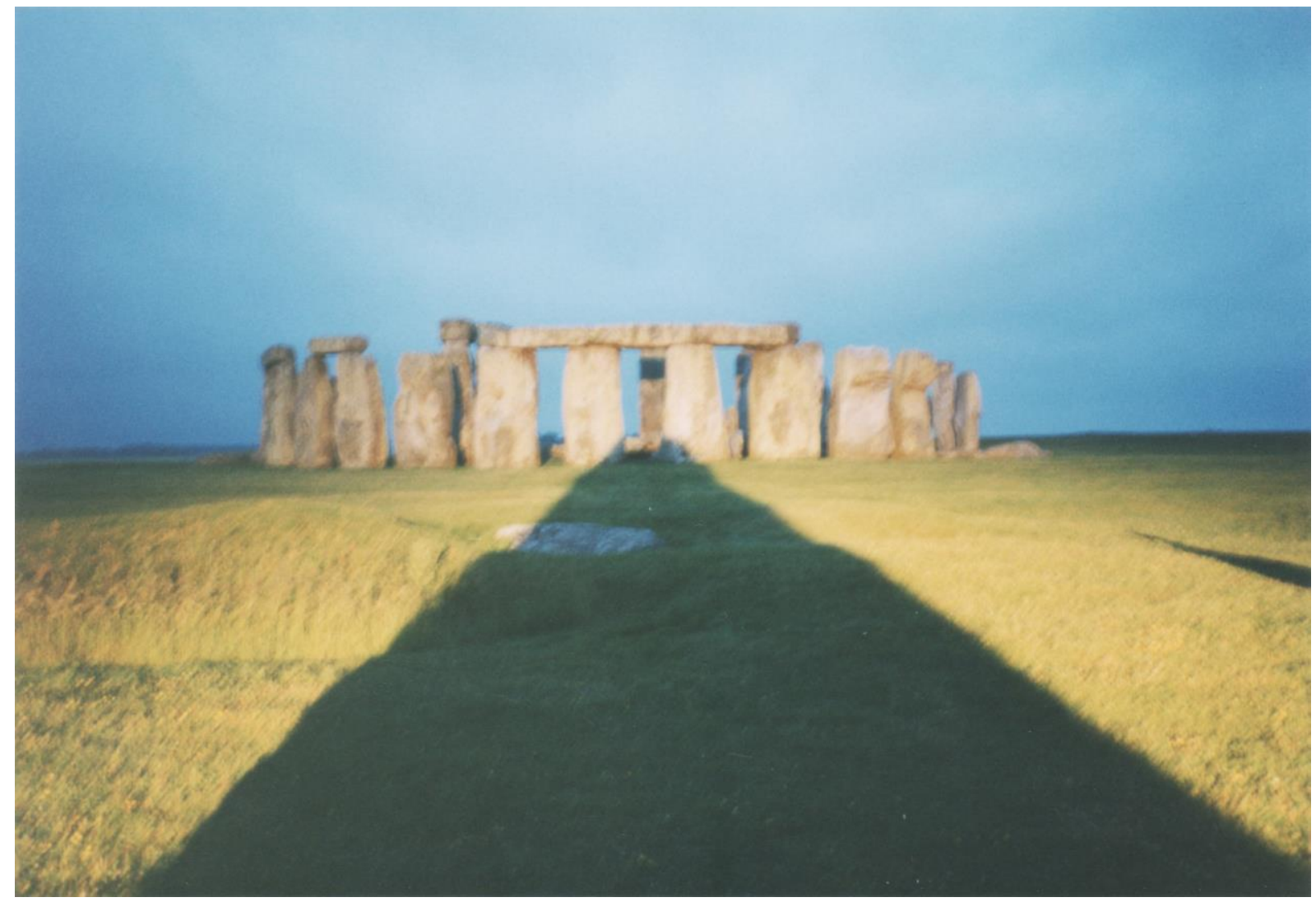

Figure 5. The ingenuity of the ancients: In midsummer week the sunrise shadow of the phallic-shaped Heel Stone enters the Stonehenge monument and reaches the focal stone called the Altar Stone. This is a reconstruction photographed by the author sitting with his back against the Heel Stone.

On many occasions the shadow cast by the full orb at sunrise can be feeble at first. For there to be a strong shadow from the start there must be no clouds on the north-eastern horizon, no mist or fog, and preferably a dust-free atmosphere as may happen following a period of rain. Usually, eyewitnesses watch a rather weak shadow entering the monument (even if too feeble for good photography) but any shadow would have been good enough for the ancient British devotees.

As the sun rises, the shadow darkens as it gains strength. Figure 6 gives an example in which the shadow, having penetrated the monument minutes earlier, is on its way out.

From the Heel Stone the author has seen the shadow fully enter the monument even when it was too weak to photograph well. Other witnesses have been inside the monument and watched the shadow reaching the Altar Stone. Snailum (1985) wrote, "We saw that the tremendously long shadow cast by the Heel Stone and passing through the central trilithon just, but only just, finished exactly upon the altar where we were sitting".

Simon Banton (English Heritage) viewing from inside Stonehenge reported (private communication), "I've observed the shadow penetrating the circle (in 2013) and I've calculated that it would reach the Altar Stone under perfect conditions." Two friends of the author in solstice week 2015 actually filmed the shadow when its tip was fully inside the monument (video film to be published).

Note how this compares with events at the summer solstice at Drombeg in Ireland (Meaden 2017: fig. 12, 16) and the Avebury Cove (this paper, Section 4.5). 


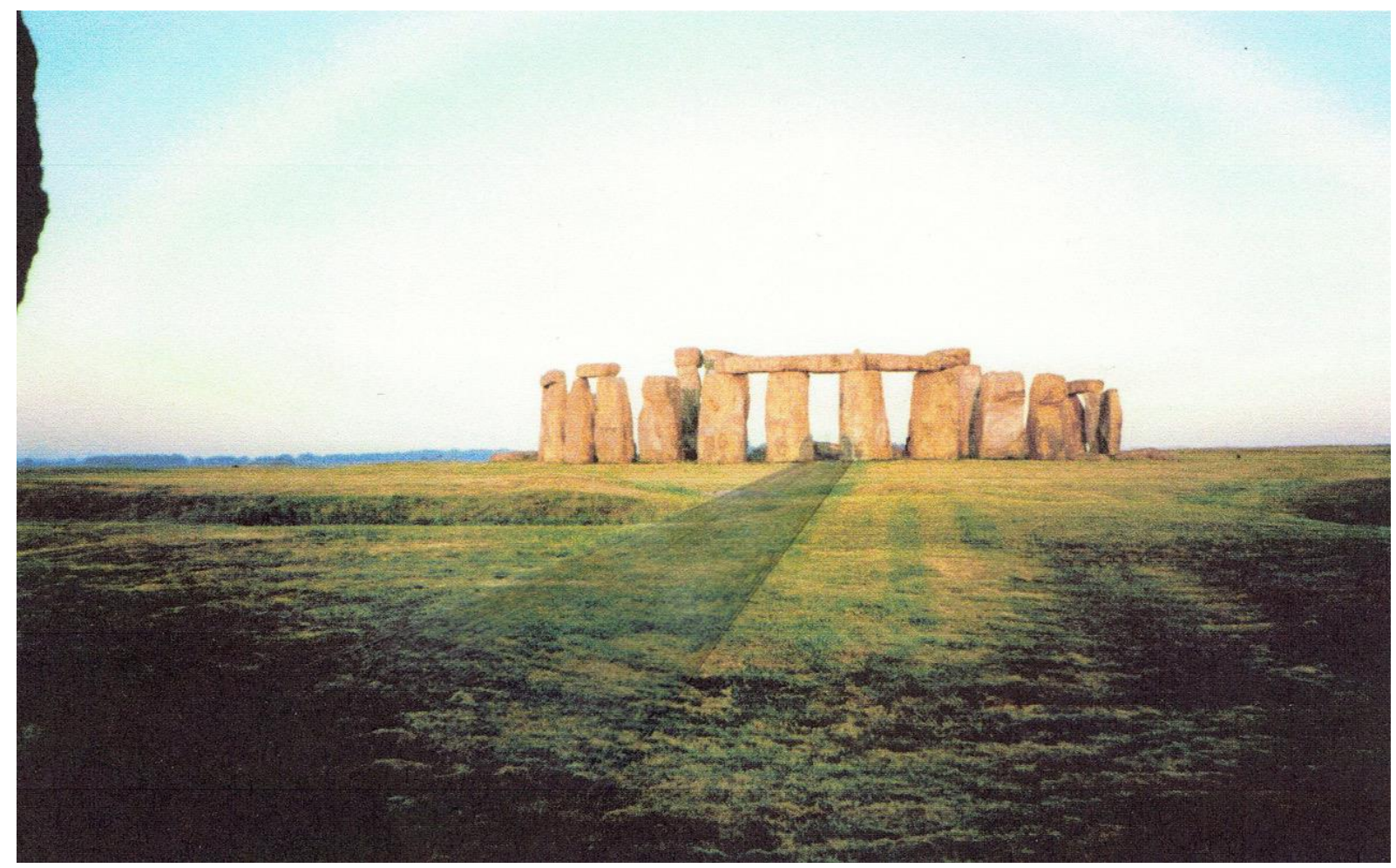

Figure 6. This photograph was taken a few minutes after sunrise on 19 June 1989 by the author standing on the Stonehenge axis. Shortly before this, the entire peak of the shadow was inside the monument between portal Stones 1 and 30. A little later as detumescence progresses and the shadow, now darker, moves to the right and is on its way out, a part is still inside while a part falls upon portal Stone 30.

The stone known as the Slaughter Stone lies prone inside the circular bank on the Stonehenge axis (refer to Figure 2 where its position is close to and just south of Hole E). In lying flat this stone has no relevance to the functioning of the present Stonehenge monument as the stones are now. The stone's function was probably purposeful in an earlier period of Stonehenge's prehistory. This matter is discussed in Section 4.4.

\section{Results for sunrise phenomena at Stonehenge at the winter solstice}

There are compelling reasons to suggest that at an earlier period in the story of Stonehenge there had been a deliberate arrangement that recognized the observation of the winter solstice sunrise in relation to lithic selection and the positioning of certain stones.

\subsection{Inbuilt alignments at Stonehenge to the winter solstice sunrise}

Firstly, the Altar Stone lies prone and in alignment with the direction of midwinter sunrise. Its position is not at right angles to the Stonehenge axis as might have been expected. Because also the axis of the summer solstice sunrise bisects the recumbent Altar Stone, it suggests that the stone was deliberately set like this - at least in the final phase of use of the monument. This has been explained independently by Daw (2015). The fall of Stones 55 and 156 that now lie upon the Altar Stone did not knock it from a standing position. Instead they fell upon where the slightly-angled Altar Stone was already lying flat in the turf where it is now (Figure 7).

Secondly, the still-standing Great Trilithon Stone 56 appears to be set parallel to the recumbent Altar Stone (Daw 2015). 


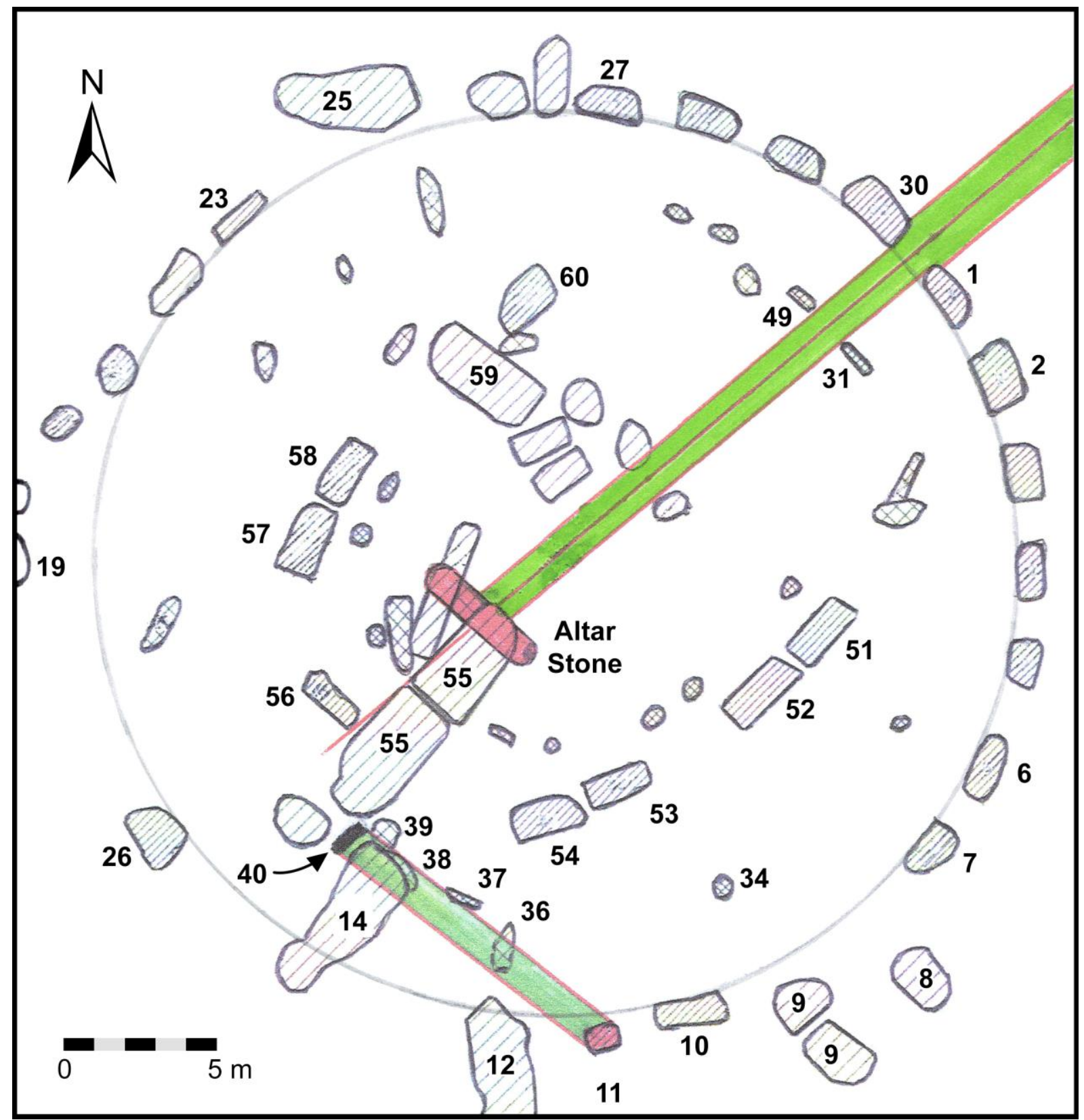

Figure 7. Two shadow casting situations are suggested in this figure. (1) The shadow from the Heel Stone that reaches the recumbent Altar Stone at midsummer sunrise; (2) the shadow from the short squat Stone 11 (at the south in this plan) with its winter solstice sunrise alignment to a stone at or near the present position of broken Bluestone 40 (shown black). Notice that the long recumbent Altar Stone is parallel to the latter line, and not at right angles to the midsummer sunrise axis of Stonehenge. The same applies to the Great Trilithon Stone 56. (Author's diagram, after Cleal et al. 1995: 27) with the discussed shadows introduced).

Thirdly, there is another alignment between Trilithon Stones 57 and 58 (Figure 8) that just misses Stone 53 and Stone 8 such that at the midwinter sunrise sunlight passes through prearranged gaps (Freeman \& Freeman 2001) as seen in the photograph taken on 27 December 2014 and follows a line that is close to and parallel to the recumbent Altar Stone. Simon Banton (2012), who told the author about this, took similar photographs in 2011 and 2012.

Fourthly, there is the major circumstance that involves the enigmatic half-size, half-width Stone 11 whose purpose has never been explained. 


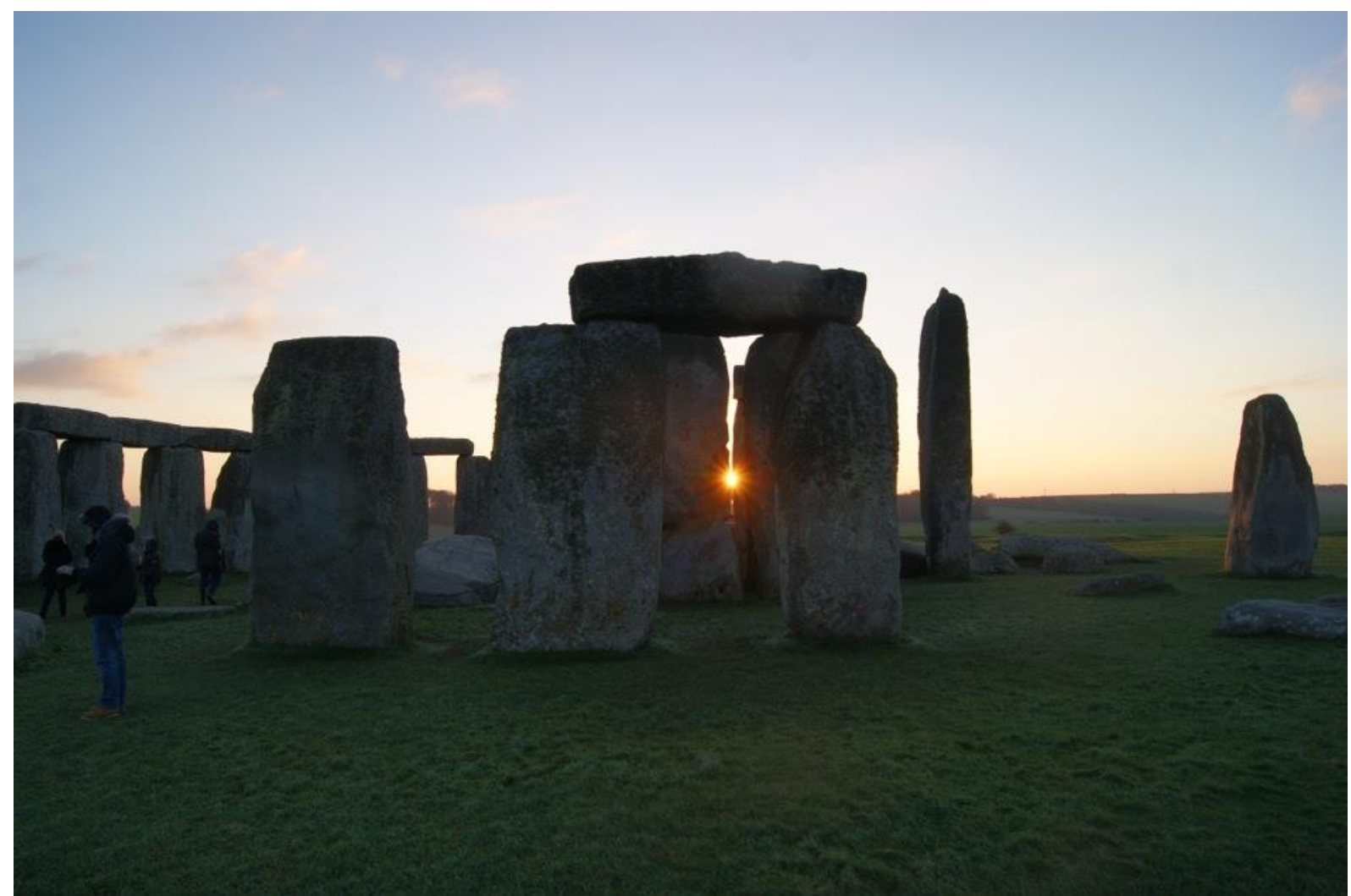

Figure 8. In the week of the winter solstice the rising sun shines through prepared gaps between the sarsens in a direction that is close to and parallel to the recumbent Altar Stone. (Photograph by the author, 27 December 2014.)

\subsection{Reasons for proposing that the half-size Stone 11 is a survivor from an earlier stone arrangement}

At the place where a tall sarsen orthostat - flat-topped with tenons - should stand on the main 30-stone outer ring, there is instead a round-topped sarsen at half the height expected for stones of the linteled sarsen ring. It is also half the width and less thick. This dwarf is numbered Stone 11 (Figures 9 and 10). Its round top is not so different from that of the familiar Heel Stone when regarded along the Stonehenge axis in the direction of midsummer sunrise, as in Figure 3. Hence, it is suggested that Stone 11 may have functioned similarly to the Heel Stone but with respect to a winter solstice alignment if the stone is a survivor from earlier times.

The 30-stone ring of orthostats with 30 lintels could never have been completed in the presence of the short Stone 11 if the latter was already present for being ancestral from an earlier stone arrangement (to which Hole G and the Slaughter Stone may also belong, see Section 4.4). This can explain why the later-built arc of the perimeter of the main sarsen circle is offset relative to the position of Stone 11 (Figure 7). It recalls the singular situation known for Drombeg in which the positions of a pillar stone and a lozenge-shaped stone are both intentionally staggered (and Drombeg's circumferential Stone 16 also subtly shifted) in order to allow a sunrise shadow of the pillar stone to fall upon the lozenge stone at the equinoxes (refer to Meaden 2017: Sections 3.3, 3.4).

Hence the major question is whether the Stonehenge builders set up an additional stone such that the shadow of the round-topped Stone 11 would fall upon it at or soon after the winter solstice sunrise. If so, has such a special stone survived the turmoil of later millennia?

Study of the plan in Figure 7 combined with the line of the photographed shadow of Stone 11 taken near the winter solstice of 2014 (Figure 11) suggests possibilities. 


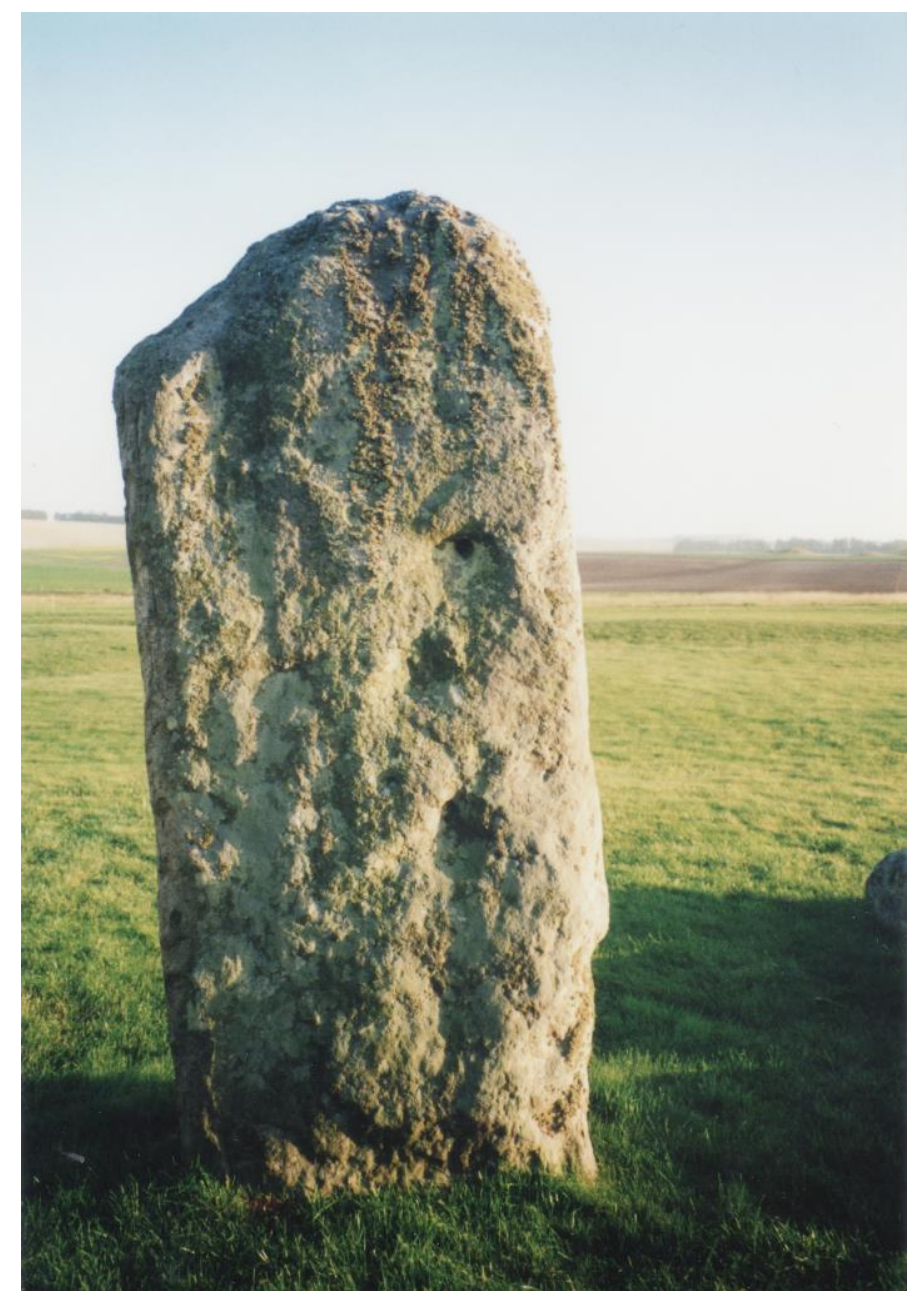

Figure 9. The short rounded Stone 11 (next to the bigger Stone 10) stands slightly offset from the true perimeter of the outer ring of tall standing sarsen stones (compare with the plan in Figure 7) and is only half their height and half their width. (Photograph by the author an hour after sunrise on 31 August 1996.)

Interior to the ring of sarsen stones (Stones 1 to 30) is a bluestone ring (Stones 31 to 49). Bluestone 40 - but now damaged - is at right angles to the circumference of the bluestone circle, while also being aligned to Stone 11 as regards the winter solstice sunrise. This ensures that the shadow of Stone 11 would make union with the waiting bluestone (an intention inferably initiated in an earlier phase of Stonehenge) (Figure 6).

The bulk of the shadow of Stone 11 misses the pointed base of the bluestone circle's fallen Stone 36 and standing Stone 37 to arrive at a place where badly damaged bluestones 38, 39 and 40 lie crowded awkwardly together. Why so close (Figure 7)? Bluestone 38 lies flat beneath the weight of the huge fallen sarsen Stone 14, and almost touching Bluestones 40 and 39. Bluestone 39 is spotted dolerite. Bluestones 38 and 40 are rhyolite ignimbrite, the only examples known for standing stones at Stonehenge (Cleal et al. 1995: 28; John 2011), so it may be that they are parts of a single ignimbrite stone broken by the fall of sarsen Stone 14. A tentative proposal is that in earlier times a single bluestone stood alone at this place in order to function solsticially with the shadow of sarsen Stone 11, and that later when the stones of the outer bluestone circle were introduced it was left in position while ensuring that the later Bluestones 36, 37 and 39 would not obstruct the shadow line from Stone 11. Its former standing position may be beneath the fallen sarsen where Bluestone 38 now lies. Hence, just as a particularly special rock type (a micaceous greenish sandstone) was chosen for the mineral to serve as the Altar Stone at the summer solstice, so might this rhyolite ignimbrite tuff have been selected to do duty at the winter solstice. 


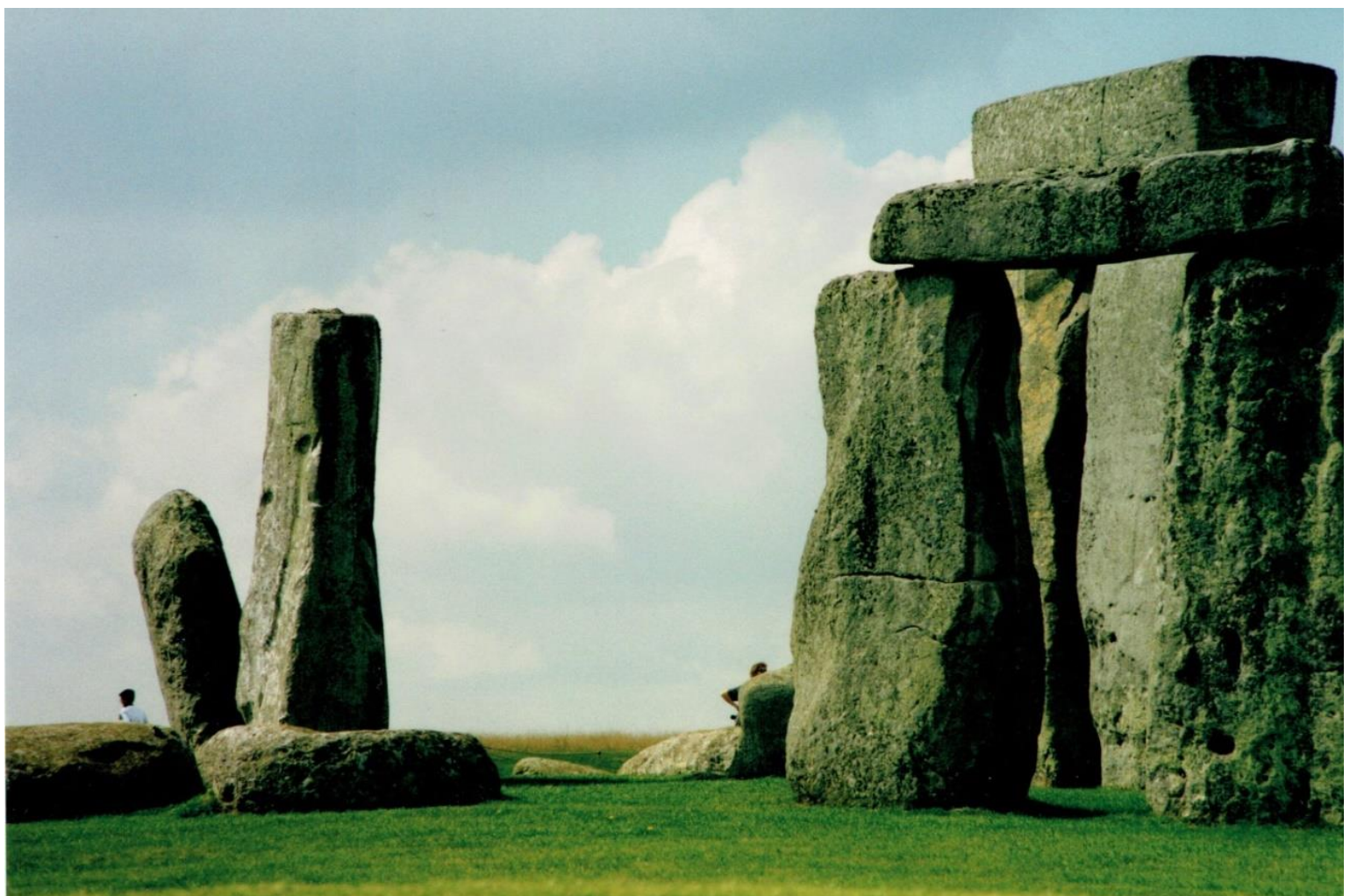

Figure 10. The enigmatic Stone 11 (leaning, at left of the picture) stands next to Stone 10 which is a normal stone of the outer sarsen circle. This emphasizes its anomalous shortness and rounded top. The nearest orthostats at the right are Stones 6 and 7. Lying battered and broken on the ground between standing Stones 7 and 10 are sarsen Stones 8 and 9 having fallen outwards. (Photograph by the author, 25 August 1997)

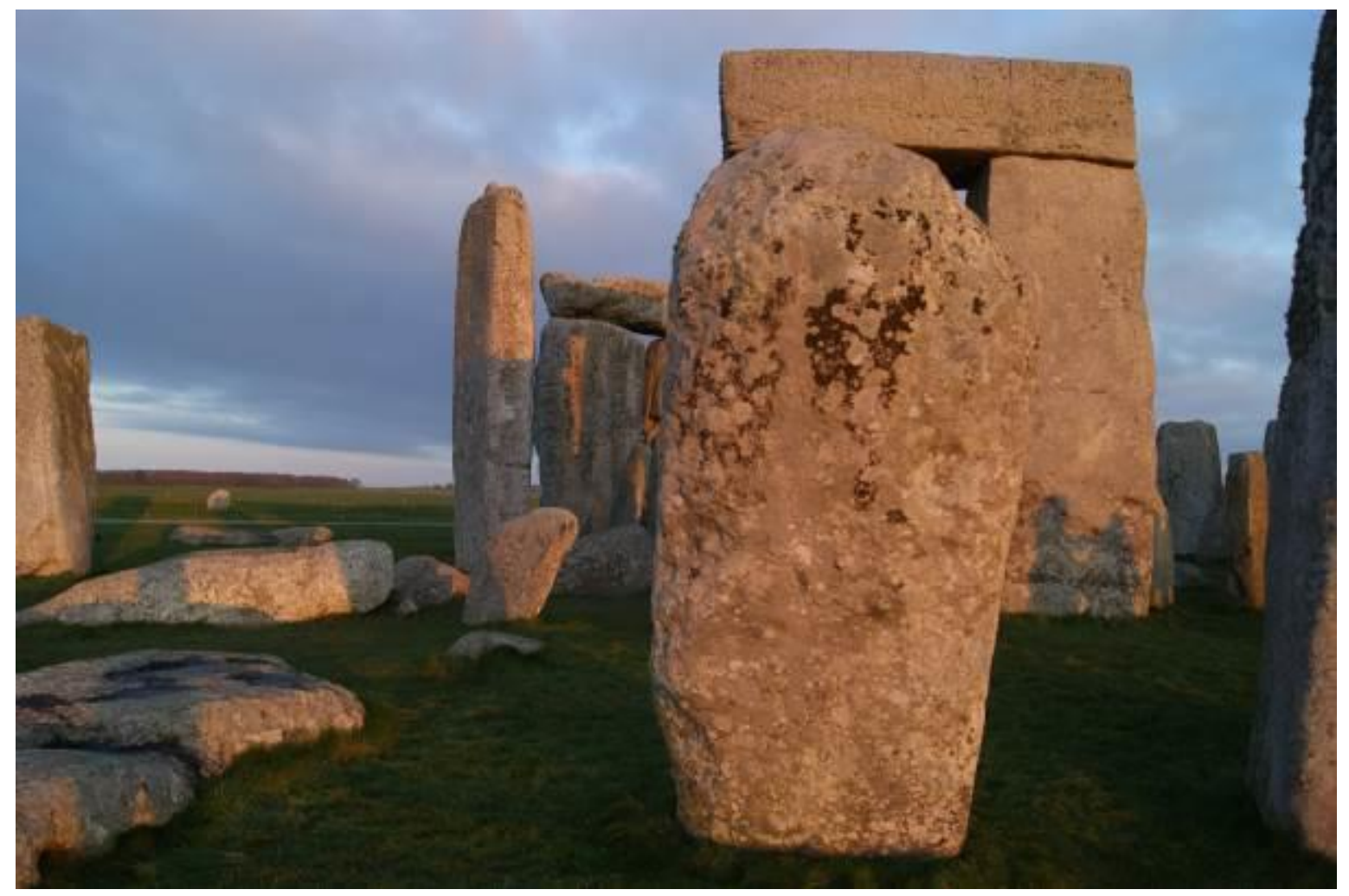

Figure 11. After a reddish sunrise on 27 December 2014, the shadow of the round-topped Stone 11 (the foreground stone) falls in the direction where part of Bluestone 40 lies just beyond the prone sarsen Stone 14 that has toppled inwards on top of the broken Bluestone 38. The latter and Bluestone 40 may be parts of what used to be a single stone. Compare with Figure 12. (Photograph by the author.) 
Excavations are warranted because none have been done in this part of the monument that embraces the settings of sarsen Stones 10, 11, 14, 15, and Bluestones 37, 38, 39 and 40 (Cleal et al. 1995: 194-195, 197, 220-221). It could have been partly out of respect for an ancestral situation that Stone 11 was left in place while the ring of linteled sarsen stones was being raised so that an ancient winter solstice bonding by shadow would continue until the last moment. But the linteled ring of sarsen stones was never completed, so the short roundtopped stone remained.

The photographs of Figures 11 and 12 taken shortly after sunrise a few days after the solstice in 2014 show the shadow of the round-topped Stone 11 crossing the fallen Bluestone 36 and part of the fallen sarsen Stone 14. However, if Stone 14 had not fallen, the said shadow could instead have directly met a rhyolite ignimbrite bluestone standing at or near this place.

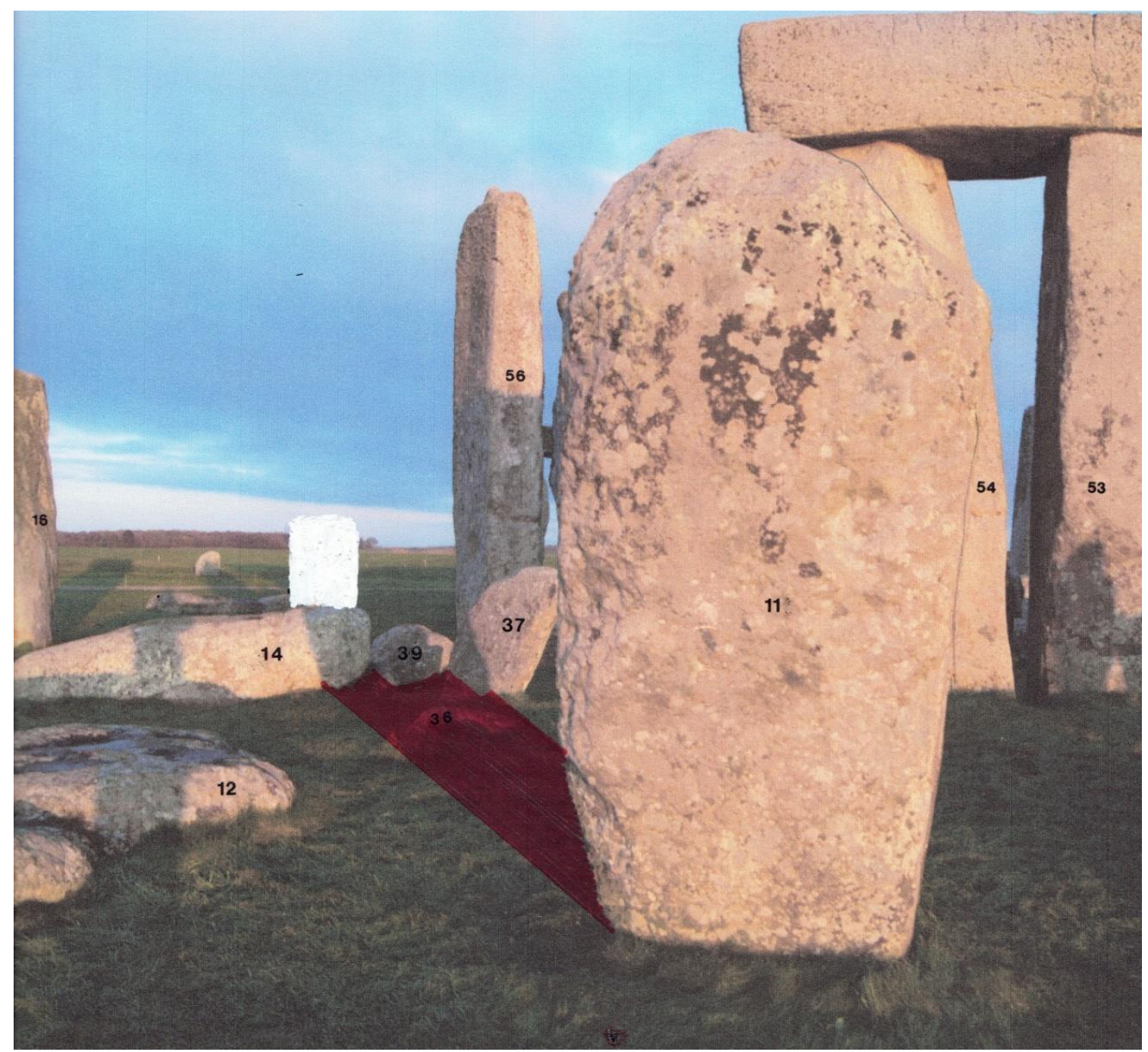

Figure 12. To help understand Figure 11 the photographed sunrise shadow of sarsen Stone 11 has been darkened and the position of a standing stone inserted at the place where Bluestone 40 is in the ground. It is shown white for emphasis and clarity. The big sarsen Stone 14 has fallen from the left and lies across Bluestone 38 which may itself be part of a once-single bluestone because both 38 and 40 are rhyolite ignimbrite, the only examples known at Stonehenge. The shadow of Stone 11 crosses the fallen Bluestone 36, grazes the upright Bluestone 37, and then crosses the broken Bluestone 38 (most of which is beneath Stone 14) and the fragment numbered Bluestone 39. Bluestone 36 lies prone has fallen from the right (compare with the plan in Figure 7 and the photograph of Figure 11). Note that this photograph was taken six days after the solstice and a few minutes later than sunrise, so this situation roughly corresponds to the position of shadows for 21 December just after the solstice sunrise. (Author's photograph). 
Compare this photograph with the plan in Figure 7 and the explanation in Figure 12. Shown white in Figure 12 for clarity of expression is a standing stone such as could be a receptor for a winter solstice shadow cast by the round-topped anomalous Stone 11 which, as explained, is not a member of the great linteled sarsen circle. In the picture the ignimbrite stone (38 plus 40) is pictured as if standing at the current position of fallen Bluestone 40 and yet, as explained above, its original stonehole may lie beneath the fallen sarsen Stone 14 close to the position of fallen Bluestone 38. These tentative suggestions can only be tested by excavation.

\subsection{Results for solar phenomena at Stonehenge at the winter solstice sunset}

In midwinter week the sun sets in the opposite direction to that of sunrise at midsummer. Observers today when standing on the Stonehenge axis outside Stonehenge at the north-east can watch the sun setting as demonstrated by the photograph in Figure 13, where nowadays the sun comes into sight just before the tallest stone, Stone 56, is reached. However, 4500 years ago the companion trilithon stone, number 55, was also standing. The sun could not then be seen until the last minute of sunset when it appeared briefly between the pair of vertical megaliths 55 and 56.

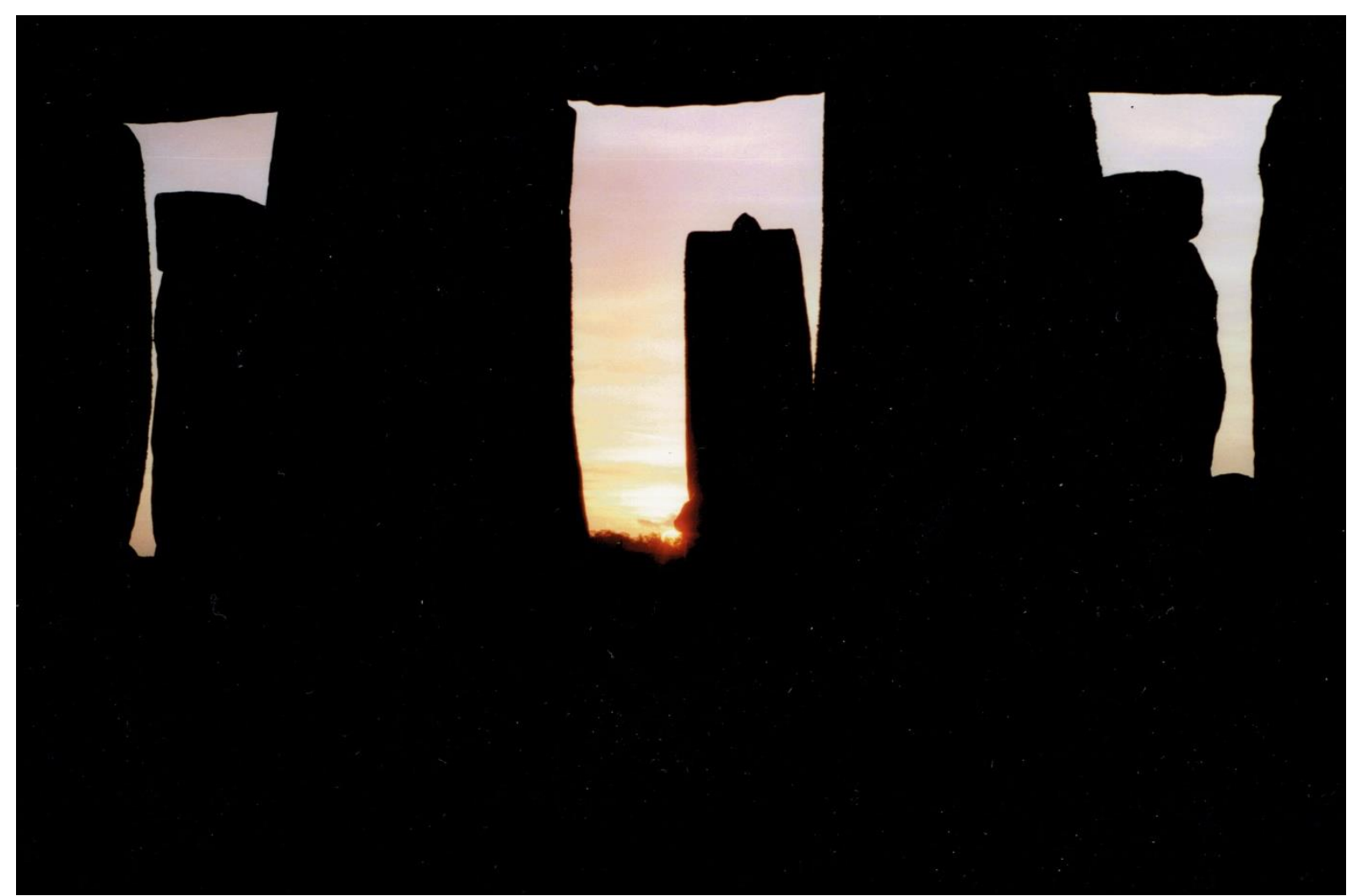

Figure 13. View from the Heel Stone of the sun setting between Stone 56 and the now prone companion Stone 55. (Photograph by the author.)

\subsection{Further results for solar phenomena at midsummer sunrise: a possible meaning for the Slaughter Stone}

The fallen stone known as the Slaughter Stone (Stone $S$ in Figure 14) lies prone alongside and south of Stonehole E (Figure 2) within the perimeter of the grand circular ditch and on a line from the Heel Stone to the Altar Stone. Cleal et al. (1995: 284-287), in considering the situation resulting from Hawley's excavation in this area, concluded (Cleal et 
al.: 287), "We do not know the exact location of the Slaughter Stone's original hole beneath its present site".

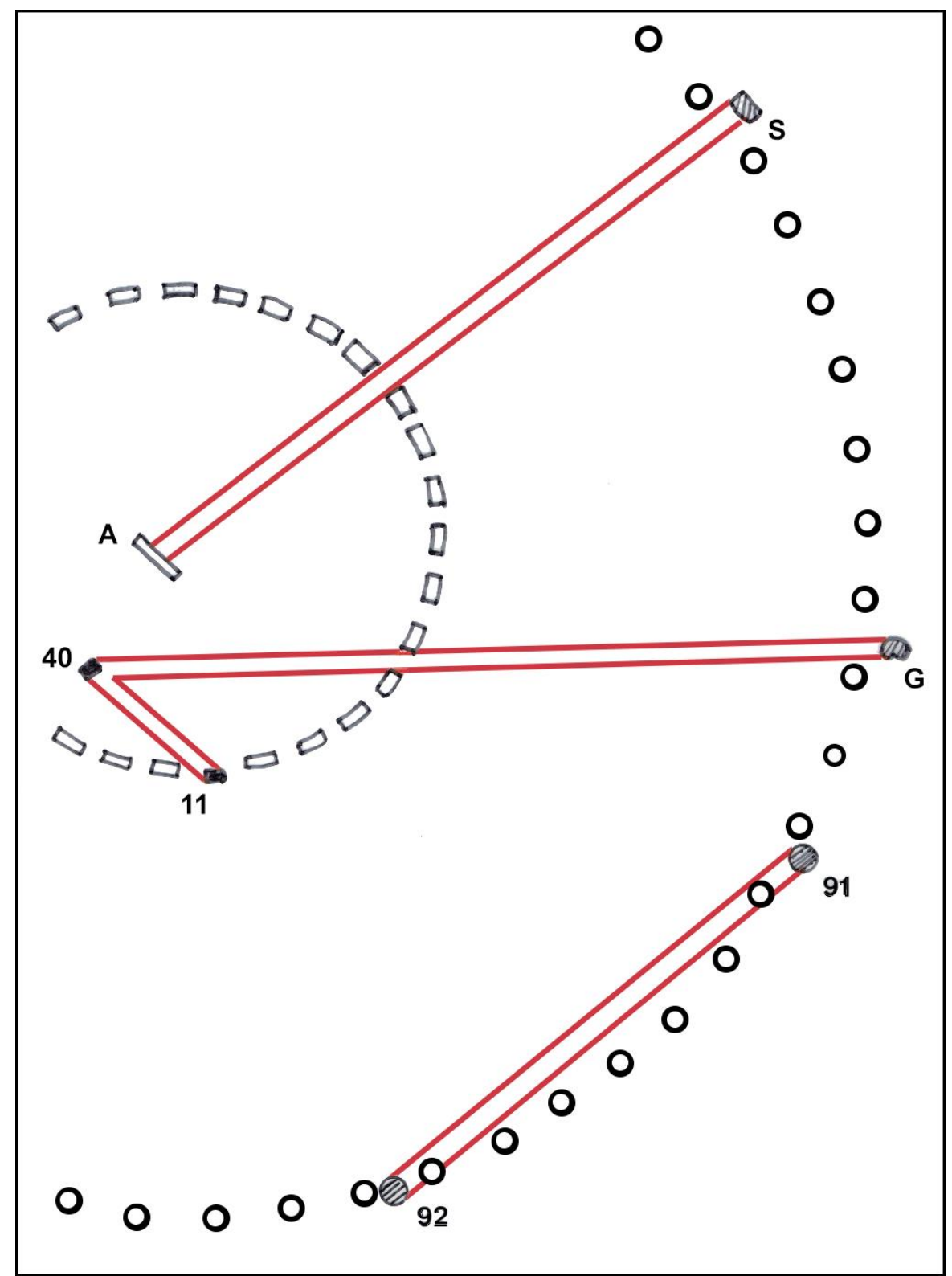

Figure 14. The plan shows the positions of seven stones or stone-holes and arcs of the Aubrey Hole circle and sarsen circle. The long axis of the Altar Stone A is towards the winter solstice sunrise, and is not, as explained in Section 4.2, exactly perpendicular to the Avenue and the summer solstice sunrise. Included is the line of shadow cast by Slaughter Stone S when standing. Additionally, the plan shows how a shadow from the short roundtopped Stone 11 would fall upon the ignimbrite Stone 40/38 at midwinter sunrise and how a shadow from a stone at Hole G would cast an equinoctial shadow upon the same stone (refer to text in Section 4.2). The two Station Stones, 91 and 92, that relate to the direction of the winter solstice sunset and midsummer sunrise are included too. The same would apply to Station Stones 93 and 94 (not shown). (Drawn by the author).

The Slaughter Stone has no relevance to the working of the present-day Stonehenge monument, but one may suggest that it could have been positioned at some stage in the history of the monument to function as a midsummer sunrise shadow maker if a decision had been made that on too many occasions at solstice sunrise the shadow from a pre-existing Heel Stone was disappointingly weak. 
As for the Heel Stone, Cleal et al. (1995: 274) discuss Bronze Age Beaker sherds found at the side of its stone hole. This leads Cleal et al. $(1995: 467,578)$ to propose a date for the Heel Stone as possibly belonging to Phase $3 \mathrm{a}$ (which is a date range of a century or so starting from $2550 \mathrm{BCE}$ ) while nonetheless allowing that its date could be earlier. Indeed, the potsherds only provide a terminus ante quem for the hole of the Heel Stone.

The length of the Slaughter Stone is $6.2 \mathrm{~m}$ but if its hole lies beneath the prone stone the hole's depth is unknown. The depth will not necessarily be similar to that of nearby Stonehole E which is $2.0 \mathrm{~m}$ (Hawley 1921: 36).

The distance of the Slaughter Stone (Stone S, Figure 14) to the Altar Stone is $45 \mathrm{~m}$. This is much less than the distance of $80 \mathrm{~m}$ for the $5.2 \mathrm{~m}$-high Heel Stone (for its height refer to the caption of Figure 3). Hence, standing upright in its hole the Slaughter Stone would cast a stronger shadow into the monument at summer solstice sunrise than would the Heel Stone.

A further suggestion is that if in antiquity it had come to pass that the Slaughter Stone, Stone S, was no longer needed for this purpose and that instead it should be preserved by partial burial in a shallow longitudinal pit in the chalk, then it was left visible possibly out of respect for its earlier significance.

However, it may be more likely that it was still standing in the late sixteenth century. Burl (1994: 77-89) deliberates the matter on the basis of Elizabethan-age engravings and watercolours, and reproduces the engraving from Camden's Britannica of 1610. Bakker (1979: 107-11, illustration in Plate 10) discusses a watercolour by Lucas de Heere ("drawn on the spot") and suggests that it dates from 1568-69. Chippindale (1983: 34-36 and facing p 48) also discusses the artistry, and includes pictures by William Smith (1588) and 'R.F.'

There is an image of Stone $S$ in the R.F. print of an imperfect Stonehenge (dated 1575) that shows Stone $S$ as a rounded boulder lying prone. In an otherwise reckless copy made for Camden's Britannia of 1610 Stone S appears upright. Many similarities, including the repetition of gross errors between these various illustrations, prove that they are descendant engravings modified by artistic licence from a lost original that was likely drawn by Joris Hofnagel in 1568-69 (Bakker 1979: 109). Neither de Heere's known watercolour of 1568-69 (Bakker 1979: Plate 10) nor William Smith's watercolour of 1588 (reproduced by Chippindale (1983: facing p. 48) show any stones at the axial entrance, but those of R.F. and Camden do (Burl 1994: 88).

In short, one must consider that Stone $\mathrm{S}$ was perhaps still upright in the sixteenth century. Importantly, it happens that from the point of view of the present research and analysis, it does not matter whether Stone S was standing or not at that time. Either way, in antiquity, a solstice sunrise shadow will have penetrated the monument whether it was thrown directly by the Heel Stone or by Stone S because they have the same alignment.

Finally, there is Hole $\mathrm{G}$ - meaning there is a possible missing Stone $\mathrm{G}$ to consider (Cleal et al. 1995: 288). An equinoctial possibility at Stonehenge is prompted by the nature of the research undertaken at Drombeg (Meaden 2017). Hole $\mathrm{G}$ is $1.2 \mathrm{~m}$ deep near the circle of Aubrey Holes in the east (Figure 13). If Hole G formerly held a stone, then as with the Slaughter Stone $S$ it is in the right position to cast a shadow into the monument - this time at the equinoxes. A target stone for a shadow from a stone at $\mathrm{G}$ could be the rhyolite ignimbrite bluestone discussed in Section 4.2.

\subsection{Results for shadow phenomena at the Avebury Cove at the summer solstice sunrise}

The Cove Stones at Avebury centre a 99-metre diameter ring of stones called the North Circle which according to Keiller \& Smith numbered 27 stones (Smith 1965: 205). A plan is provided in Figure 15. 


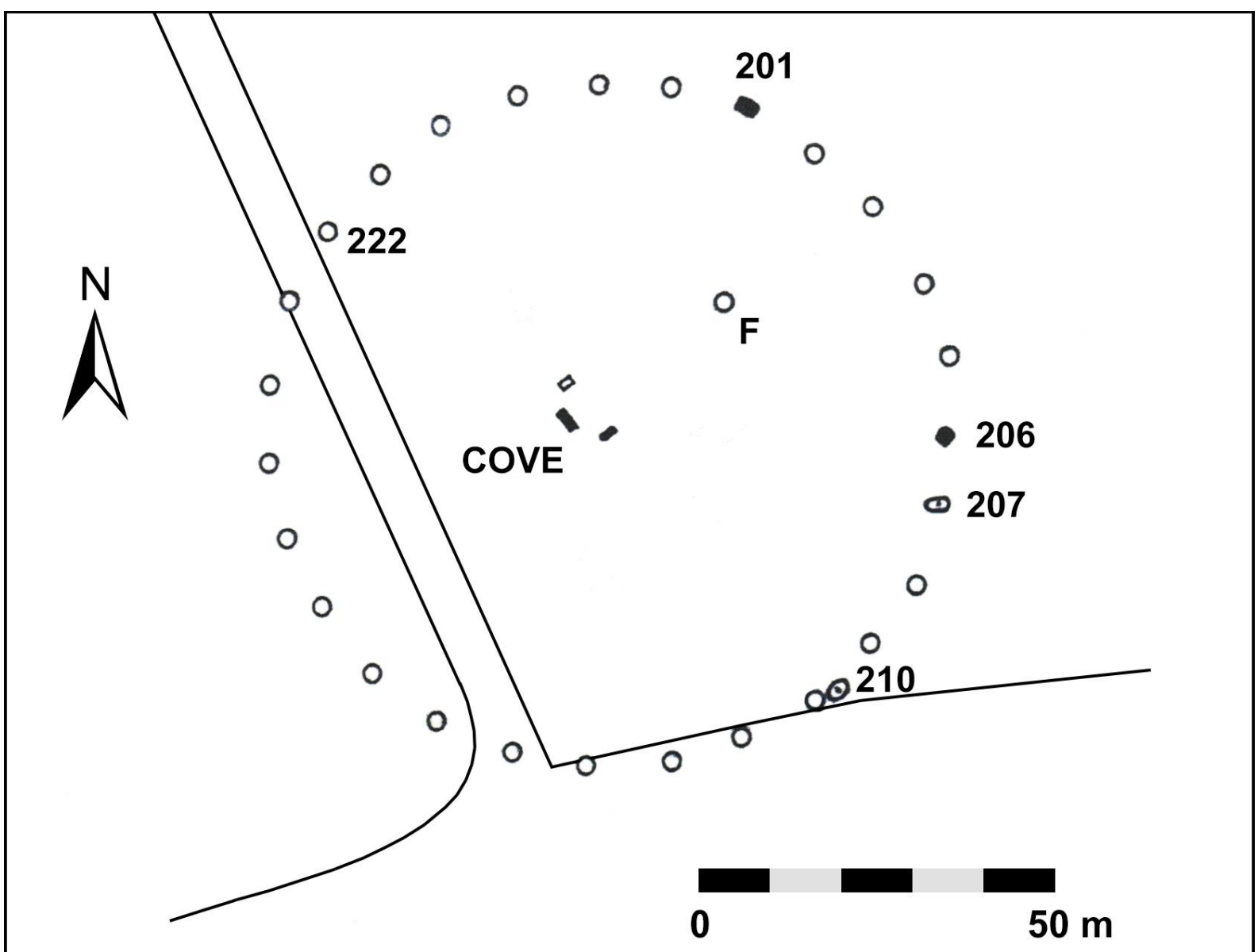

Figure 15. Plan of the North Circle at Avebury centred by the Cove. Note the position of Stone F that functions at Avebury in the same manner as the Heel Stone at Stonehenge and portal Stone 1 at Drombeg. Drawn by the author after Smith (1965: 205, fig. 70).

Nowadays at Avebury the sun rises at 51.5 degrees east of north, being delayed from the time and direction applicable to a low flat horizon by the presence of the hill known as Totterdown, a part of Hackpen. 4900 years ago in the Late Neolithic the direction of midsummer sunrise would have been about one degree less than 51.5 because of changes in the inclination of the ecliptic that occur at a rate of about 0.2 degree per thousand years, giving an azimuth of 50.5 degrees east of north. The axial orientation of the Avebury Cove is close to this figure.

In addition, a fourth standing stone (known as Stone F) - which operated as if part of the Cove - was some 25 metres distant and almost exactly on the same alignment (Smith 1965; 2015: fig. 70; Meaden 2012b). It is this stone, now missing but its position known that could have functioned at Avebury with regard to the midsummer sunrise as does the Heel Stone at Stonehenge and as does portal Stone 1 at Drombeg (Meaden 2017: fig. 12, 16).

The photograph in Figure 16 shows the current midsummer sunrise in the absence of Stone F - destroyed in the nineteenth century. This stone is critical to the proper functioning of the Cove. The watercolour painted by J. Browne in 1825 shows that Stone F was by then seriously damaged (Gray 1935: 108) (Figure 17).

The midsummer sun having risen over Totterdown Hill shines on Stone F whose shadow pairs with the waiting Cove stone. This is illustrated by Figure 18 drawn on the basis of Stukeley's 1723 sketch of the Cove relative to Stone F, to which the summer solstice shadow of Stone F has been added. Only at midsummer could this happen at the Cove. The arrangement was well planned and executed, as at Stonehenge and Drombeg. 


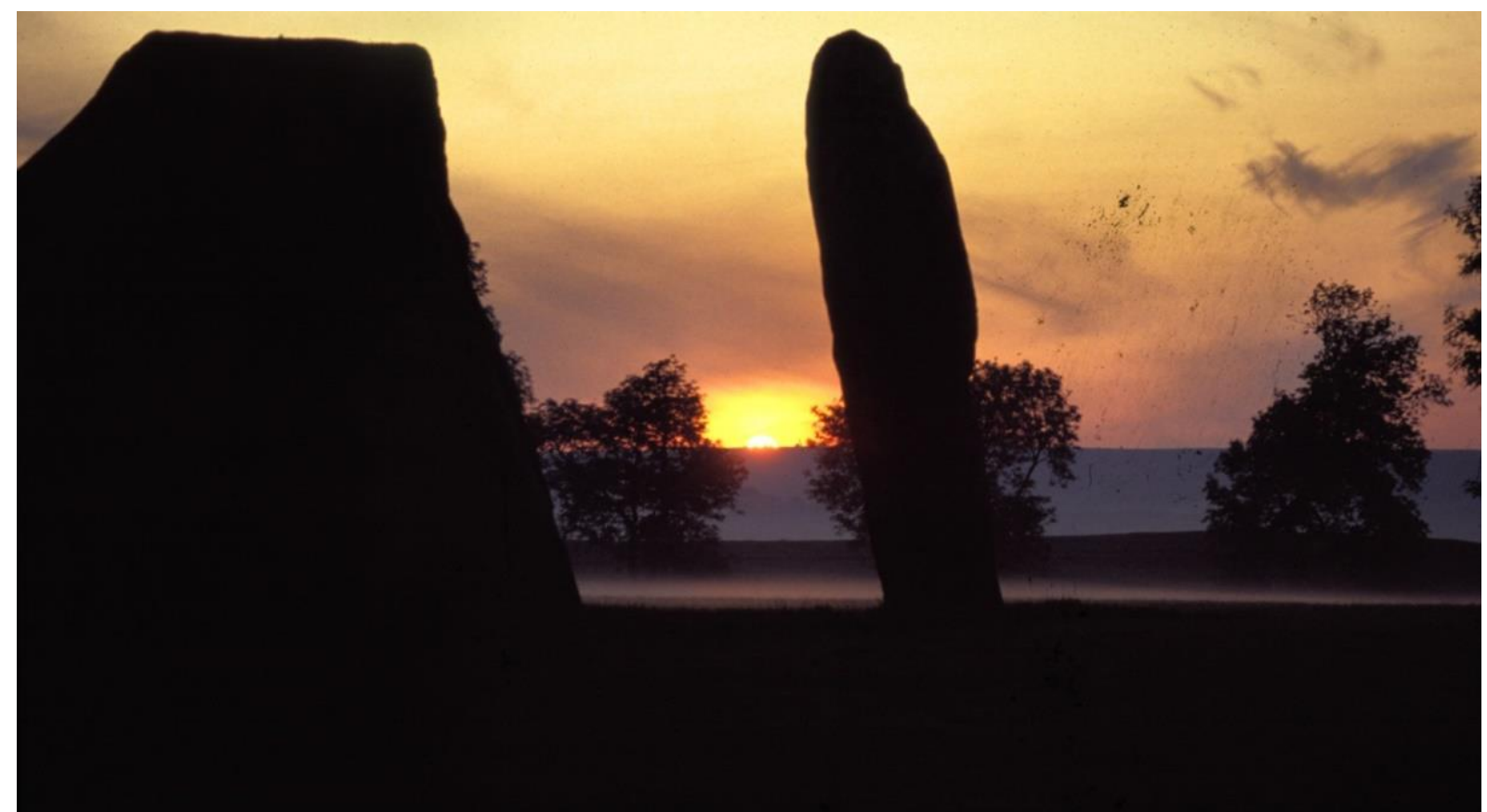

Figure 16. At the Avebury Cove looking north-east at the time of sunrise in midsummer week 1991. (Photograph by the author.)

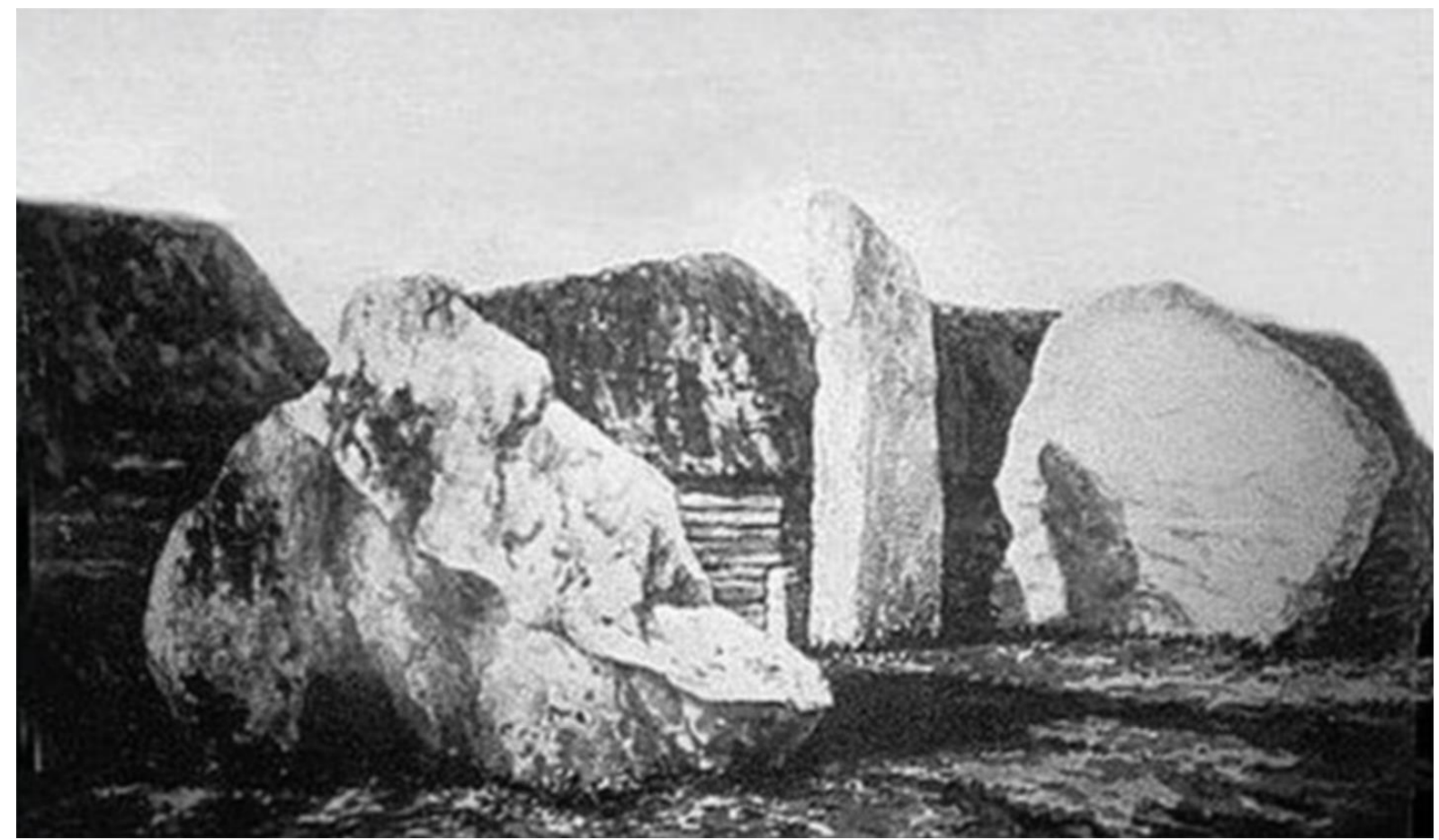

Figure 17. A watercolour of the damaged Stone F at the Avebury Cove, 1825, by J. Browne (H. St. G. Gray 1935: 208).

\subsection{Results for shadow phenomena at Avebury's South Circle at particular sunrises}

Avebury's Stones 105 and 106 of the South Circle also function in relation to a positioned stone and the sun rising over the eastern hills at the summer solstice and Beltane respectively. The $6.5 \mathrm{~m}$ long Obelisk (measured in 1723 by Stukeley (1743: Plate 16) as 21 feet long) that centred the South Circle is the stone that cast shadows at sunrise for the dates of the early May start-of-summer festival (Beltane) and the summer solstice (Figure 19). This pillar-like stone was destroyed in the 18th century, but Alexander Keiller found its stonehole 
and in 1939 marked its position with a concrete post (Smith 1965: 198, 200, 205). This allows alignments to the surviving Stones 105 and 106 to be determined, as explained by the plan in Figure 20. See Figures 21 and 22 for photographs of these stones.

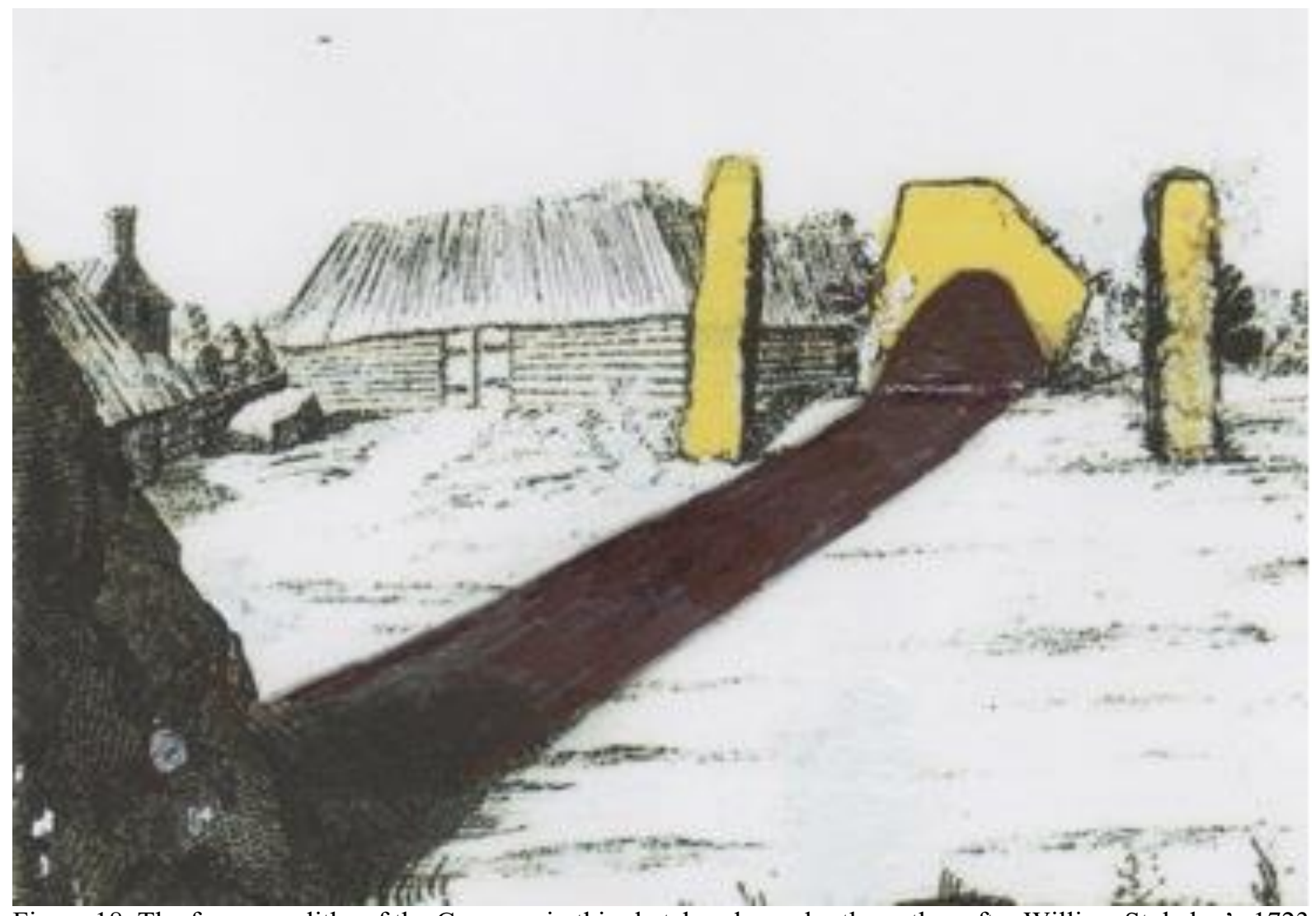

Figure 18. The four megaliths of the Cove are in this sketch redrawn by the author after William Stukeley's 1723 sketch in order to include the missing tall narrow Cove stone at the extreme right. Stone F is at the left. Soon after sunrise at the summer solstice its shadow falls on the middle Cove stone (after Stukeley 1743: facing page 25).

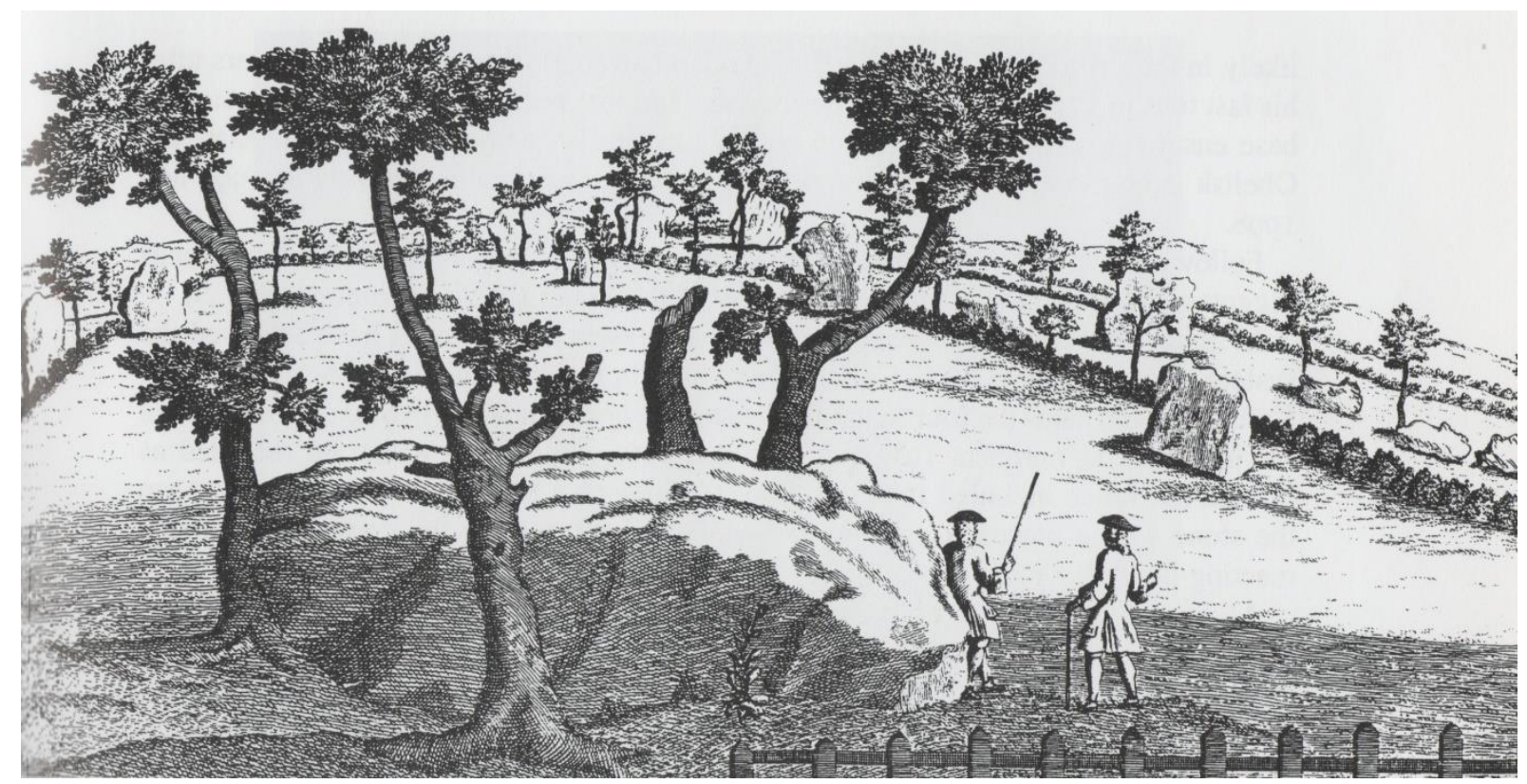

Figure 19. William Stukeley's sketch of the Obelisk which he measured in 1723 as 21 feet in length. (Stukeley 1743: plate 16, facing p. 30). 


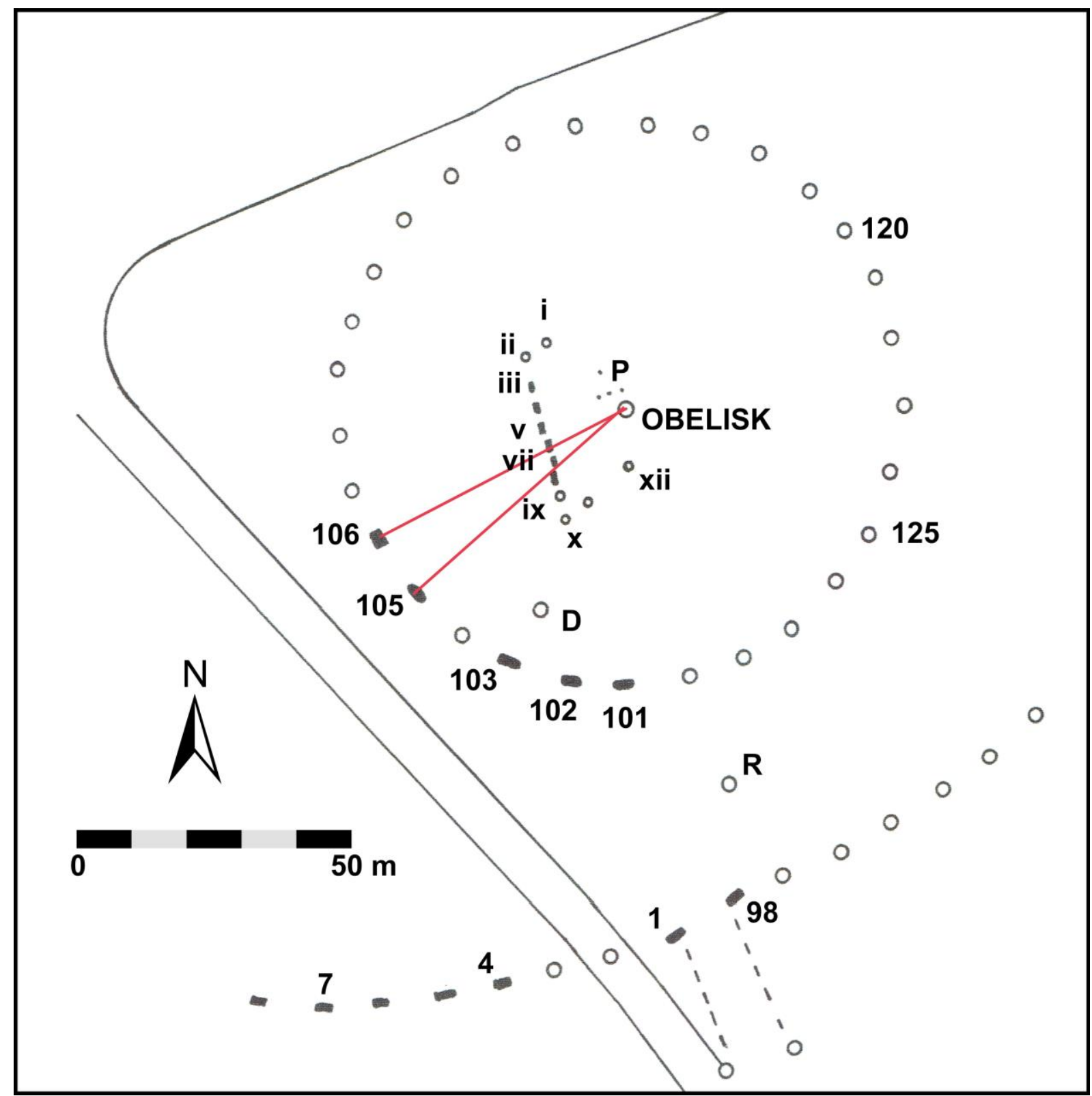

Figure 20. Plan of the South Circle at Avebury showing the relationships of Stones 106 and 105 with the directions of the Obelisk and Beltane at the summer solstice sunrises (drawn by the author after Smith 1965: 205).

Significant may be a related finding of another stone on the same sunrise alignment that terminates at Avebury's Obelisk and Stone 106. The additional stone lies prone on the false crest of the eastern hills where the Beltane sun rises at 62.5 degrees east of north. It has a symmetrical five-sided shape with a groove pecked medially (Figure 23). The man-made groove is coloured red by the presence of algae haematococcus pluviatus. The stone is placed to denote the sunrise position as seen from Avebury.

This concept of a horizon marker is repeated for the line from the horizon that ends with the Obelisk and Stone 105, because it too has a marker stone on Totterdown. Among five other placed stones on the false crest of the eastern hills that relate to stone positions of Avebury's South Circle there is another five-sided stone with an artificially pecked groove that relates to the sunrises at Imbolc and Samhain. It is suspected that the shadow phenomena at Avebury worked for all eight traditional festival dates of the farming year as has been demonstrated for Drombeg (Meaden 1999; 2016). 


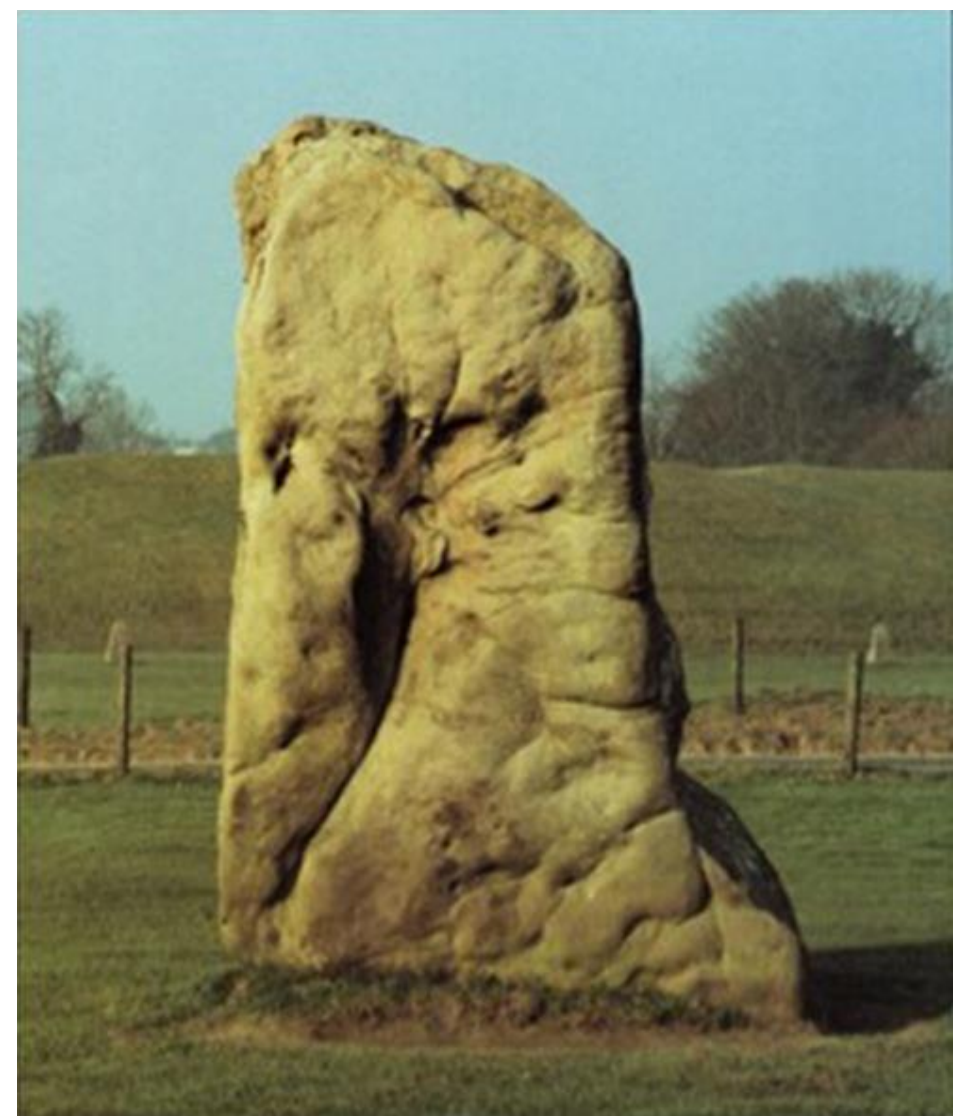

Figure 21. Stone 106 of the South Circle at Avebury was set to align with the Obelisk such that at Beltane sunrise the shadow of the Obelisk would fall upon it (compare with the plan in Figure 20). (Author's photograph)

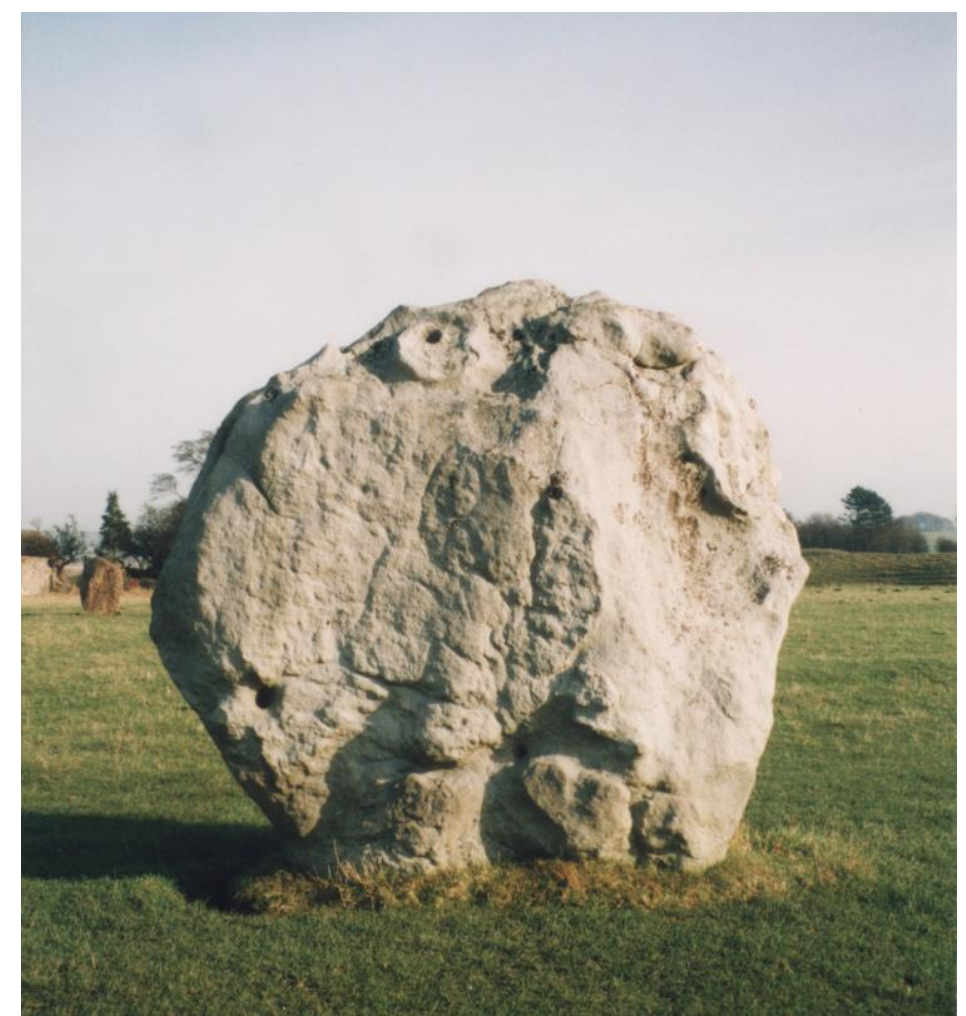

Figure 22. The roundish Stone 105 of the South Circle at Avebury was set to align with the Obelisk such that at the summer solstice sunrise the Obelisk shadow would fall upon it (compare with the plan in Figure 20). (Author's photograph) 


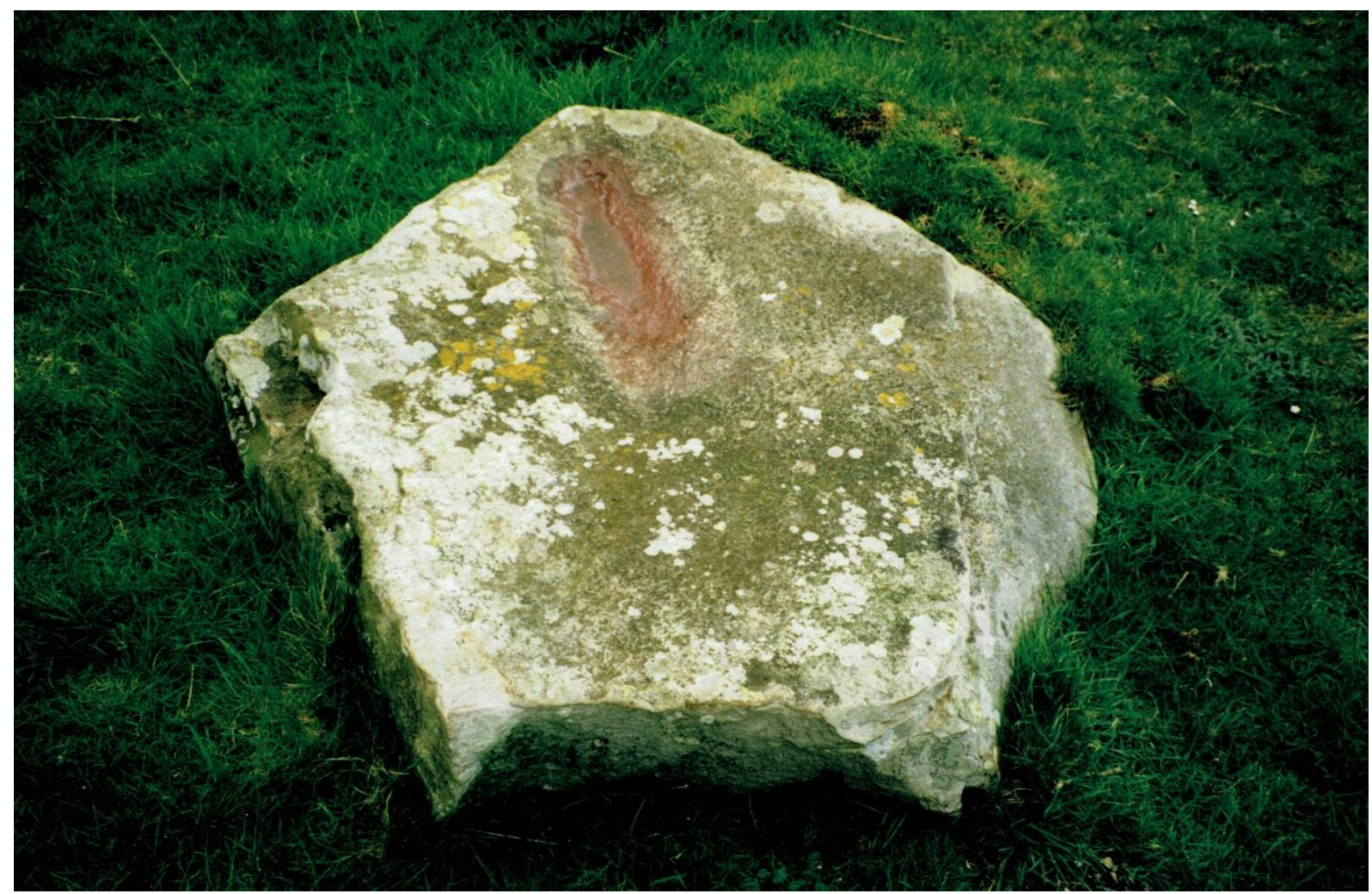

Figure 23. This shaped stone with medially pecked groove is on the hills east of Avebury. It marks the false crest near the Ridgeway where the sun rises at Beltane as seen by watchers at the South Circle. (Author's photograph)

\section{Conclusions}

This research investigated how at Stonehenge and Avebury positioned stones of particular shape or outline are able to transmit watchable meanings arising from solar movement by the creation and displacement of shadows. The purposeful engagement of shadows between particular stones was arranged to take place at sunrise, and the optimal occasions were special dates of the agricultural calendar year, above all the solstices. In a companion paper similar effects involving sun and moving shadow were announced for the stone circle at Drombeg in County Cork, Ireland (Meaden 2017).

Demonstrated first was how at Stonehenge it was arranged that in midsummer week the light of the rising sun would shine along the Stonehenge axis and enter the portal gateway to illuminate the Altar Stone. The shadow of the round-topped Heel Stone followed soon after. Today, 4500 years after the idea was first staged, eyewitnesses testify as to how the shadow continues to return every midsummer week to reach the micaceous Altar Stone - the only week of the year when it can do so. The diminutive round-topped sarsen Stone 11 behaves similarly with respect to the ignimbrite rhyolite bluestone 38 and/or 40 at the winter solstice sunrise. Later in the day the midwinter sun sets along the axis of the monument.

The concept is similar for Avebury's North Circle in which the light of the rising midsummer sun shines on the principal feature, the great Cove Stone, soon followed by the shadow of an intermediary stone (Stone F, destroyed in the 19th century). At Avebury's South Circle similar effects took place annually until the villagers destroyed its centrepiece, the pillar-like Obelisk, in the 18th century.

Hawley (1928: 176), summing up his years of excavation at Stonehenge 1920 to 1926, added that it "was no doubt first and foremost a temple and secondly a place of assembly where priests and military nobles dispensed justice and promulgated laws. It would be a wellknown landmark, a centre for trade, and a nodal point." 
It is timely to enquire how far an understanding of the meaning of such monuments can be interpreted by 21st-century scholarship. Recently, Silva and Campion (2015) treated the role and importance of the sky in archaeology. Citing Campion (2015), "recent scholarship, emerging from new disciplines such as archaeoastronomy and cultural astronomy, has argued that a complete understanding of the human environment and culture must include the sky as well as land and sea/water".

For Stonehenge and Avebury no research as to the effect of shadows cast by specific standing stones has been done hitherto. Regarding Newgrange and the effect of shadows cast by individual stones Prendergast (1991) examined surviving standing stones of the Great Circle for solar calendrical functions (further treated by Meaden 2017). The former demonstrated meaningful shadow phenomena for sunrises at the winter solstice, the equinoxes and the intercalary dates between - altogether five calendar dates of the winter half of the year (Prendergast 1991: 14, fig. 5). In turn, three different stones at Newgrange cast shadows on the waiting recipient which is the entrance kerbstone. Depending on which occasion Prendergast showed how the moving shadows either skirt the edges of the deeply carved triple spirals or largely cover them. Pursuing this proposal Prendergast (1991: 18) concludes, "this suggests that part of the Great Circle may have been used as an eight point calendar". The present author, unaware of Prendergast's research, studied this in 2014 for the winter solstice sunrise noting how a lithic shadow covered the south-western carved lozenges on the Newgrange entrance stone and continued by skimming the edges of the triple spirals (Meaden 2017). The effects of shadow-casting at Avebury's South and North Circles were studied too (Meaden 1999: 20-29, 66-75) besides the aforesaid work at Drombeg (Meaden 2017).

Pásztor (2000) and Pásztor et al. (2011) considered the effect of midsummer sunrises at Stonehenge from the point of view of a strong brightness that arises inside the monument due to direct light and reflected light coupled with shade. Pritchard (2016) has researched the casting of shadows between pairs of standing stones in West Wales.

Bradley (1989) rather differently discussed matters of darkness and shade in the interiors of megalithic-chambered tombs using examples from the south of Brittany.

The author's research at Stonehenge began in 1981, and into megalith shadow casting in 1985. Heel Stone photographs were taken in the week of the summer solstice in many years from 1986 to 2014. The first photographs published were taken in 1987 and 1989 (Meaden 1992: plates 13, 14, 15).

The Irish archaeologist Professor Ronald Hicks (1985: 72-73) in considering astronomical traditions of ancient Ireland and Britain wrote, "In early monuments ... there are tales that associate stone circles and henges with the old cross-quarter days and the solstices, some of these associations being in the form of place names, like the proposal by Ó Ríordáin \& Daniel (1964: 16) that the name Newgrange is an anglicization of An Uamh Gréine, meaning the cave of the sun." The same author concluded (Hicks 1985: 79), "This strongly suggests that it was an attempt to symbolize the midwinter sun impregnating the earth so that it would again bring forth food for the people." For various reasons involving local mythology he declared "it is hard to resist the suspicion that the agricultural cycle, and thus the year, the seasons, and astronomy are intimately involved in it." Grinsell (1976) compiled much on the matter of folklore linked to British ancient monuments.

Fahy (1959: 21) in his excavation paper about Drombeg Stone Circle when discussing the positions of specified shaped stones (Stones 14 and 15 as being lozenge and phallic shaped) said that the situation "... tends to suggest that at Drombeg we are dealing with another instance of symbolism which by its nature ought to be connected with a fertility cult". He further emphasized (Fahy 1958: 25) that "the axial orientation of the circle confirms that the midwinter sunset played a major role in the religious practices of its builders who, if we 
admit the proffered interpretation of Stones 15 and 14 as male and female symbols, would appear to have practised a fertility cult".

Agricultural societies worldwide knew that successful fertility of grain, animal stock and women were paramount for the security of their farming livelihood in addition to uncertain and fickle prospects from hunting. Most Neolithic societies held diverse but generic beliefs concerning mortuary practices that expressed considerable interest and deep respect for their ancestors. Fowler (2010) and Smith \& Brickley (2009) discuss such matters for Britain and Ireland. More specifically as to what concerns prehistoric ritual and religion there is the multiauthor volume edited by Gibson and Simpson (1998) which centres on what can be learnt from monuments and their remains. Additionally helpful in prehistoric contexts are the studies by archaeologists Merrifield (1987), Edmonds (1999), Cooney (2000), and Bradley (2007). As for Mother Earth concepts they were likely widespread long before the arrival of the great patriarchal religions and their very different belief systems (Das 2014; Gimbutas 1989; 1991; Meaden 2012a). In fact, a Divine Mother figure seems to have been prevalent in continents worldwide as prehistory gave way to recorded history (personal communication with Ronald Hutton on 29 May 1998). The concept of a divine mother and divine father was then not only a universal worldview (Eliade 1958: 38-123, 239-264) but it still is for some tribes living today (e.g., Das 2014). Partly this may be a consequence of fundamental images present as psychological archetypes. Eliade (1958: 216-238) helpfully discusses examples of how early mankind viewed epiphanies, signs and forms in stones held to be sacred. To this day in parts of tribal India - as with the proto-Australoid Kolarian Mundari tribes of Jharkhand and elsewhere - the practice of raising megaliths persists, together with associated ideas of Mother Earth, of Sacred Marriage belief complete with festivals, and of fertility settings in stone. Das (2014: 31-34) provides contemporary examples.

One is the Sarhul fertility festival: "Sarhul celebrates the marriage between the Mother Earth and the Father Sky. The festival also celebrates the earth becoming fertile ... which is signalled by the blossoming of the Sal tree (Shorea robusta). The blooming signifies that Mother Earth is all set to produce as she is fertile now, hence farming can commence ... For the tribals Sarhul also beckons the beginning of the New Year." Das (2014: 31) adds, "A similar three day fecundity festival is celebrated by the Hindus in East India known as Ambabuchi occurring on or a day later to the Summer Solstice." He further says, "Among several tribes in North-East India where megalith erection after death continues uninterruptedly, many monuments are dedicated to Mother Earth." It is reassuring that tribes still exist in Asia and the Americas whereby anthropologists and archaeologists can continue to obtain explanations like these from living communities. For the native Indians of North America Krupp (1997: 97-125) is among those who have studied similar aspects of indigenous traditions that today continue to demonstrate beliefs as to time-honoured views of an Earth Mother and Sky Father.

If for the British and Irish megalithic ages the primary fertility deity was female, one may ask to what extent cooperation with a solar sky god may have been thought to provide farmers with fertility success - such as rich soils, fecund livestock, fertile women, and appropriate seasonal weather (Eliade 1958: 239-242, 256-262, 331-341, 354-366). The concept proposed in this paper implies hierogamy - a spiritual worldview between deities known as Sacred Marriage. Such an understanding has long been known for classical literary times in countries of the Mediterranean, the Near East and Middle East, besides widely across the primitive tribal world of the continents and Pacific Ocean islands (passim in Burkert 1985: 108-109, 132-134; Campbell 1974; Eliade 1958; Frazer 1957). The rite of Sacred Marriage was a wellloved practice of agricultural communities. Kramer (1969) goes into detail and summarises by writing that the idea of "Sacred Marriage" was "joyously and rapturously" celebrated in the ancient eastern Mediterranean for more than two thousand years (Kramer 1969: 49). Cook 
(1940: 1025-1065) has detailed at length the hieros gamos that was so long cherished and celebrated in classical Greece, its origins dating from prehistory.

In the present paper about Neolithic and Bronze Age Britain the proposal is that beginning in the Neolithic there may have been a legendary belief in male-female episodic mating of the divine that was interpreted via shadow interaction between stones. This would predate the known historical accounts of the Eurasian perspective and practice of Sacred Marriage. The suggestion is that the stones of Stonehenge and Avebury were perhaps arranged for the enactment of a visual spectacle observable by big numbers of people at the solstices and at other dates of the agricultural calendar. The additional Stonehenge mystery regarding the purpose of the anomalous short phallic-like Stone 11 in the outer ring of otherwise lintelled sarsen stones could be interpreted in this context too, as similarly the equinoctial sunrises and sunsets at Knowth involving pillar stones, the winter solstice sunrise at Newgrange, and all eight agricultural festival dates at Drombeg as explained by Meaden (2017).

Stonehenge was likely an influential multifunctional centre for business, trade, and exchange particularly at the time of agricultural festivals, besides serving as a religious centre and ancillary cemetery (Parker Pearson \& Ramilisonina 1998a; 1998b). It has been argued that one such business may have centred on the idea - advocated by Darvill and Wainwright (2009) - that Stonehenge could have served as a centre for healing, partly on account of supposed medicinal benefits arising from the properties of the Welsh bluestones, because this too could explain the enduring Stonehenge folktale on this matter that was recorded in Medieval times (Atkinson 1979: 190-191; Chippindale 1983: 44, 159). Darvill (2006: 141146) suggests possible links to divinities for Stonehenge, and summarizes some of the known solar and lunar features, the idea of a cult centre, and the oracular suggestion by Curnow (2004: 1-8) of a "possibility that Stonehenge was an oracle, a place to which people made pilgrimages in order to contact the supernatural, the gods or the dead, possibly at specific times of the year..." (Darvill 2004: 146).

Whatever the original intentions of the planners, it is here proposed that dramatic art accomplished by moving shadow between chosen stones was intelligently combined with religion in a manifestly moving spectacle - a play without words, a masterwork achieved through intentional lithic planning to provide reassurance to hardworking devoted farming communities.

\section{Acknowledgments}

The author thanks Professor Luiz Oosterbeek who heard the author lecture on this subject in 2012 at the International Summer School on European Prehistory at Bonorva, Sardinia, for his considerable encouragement and invitation to run a session at L'Union Internationale des Sciences Préhistoriques et Protohistoriques, UISPP, in Burgos, Spain, September 2014. Subhashis Das has usefully supplied much information about lasting beliefs and traditions in India regarding age-old fertility rites and annual festivals among today's megalith-using tribal communities. Also the author's thanks go to Simon Banton (English Heritage) who was inside the middle of Stonehenge in 2013 when he witnessed the tip of the shadow of the Heel Stone entering the innermost part of the monument.

\section{References}

Atkinson, R. J.C. 1956, Stonehenge. Hamish Hamilton, London, 210 p. 
Atkinson, R.J.C. 1978, Some new measurements on Stonehenge. Nature, 275: 50-52. doi:10.1038/275050a0

Atkinson, R.J.C. 1979, Stonehenge: Archaeology and Interpretation. Penguin Books, London, $224 \mathrm{p}$.

Bakker, J.A. 1979, Lucas de Heere's Stonehenge. Antiquity, 53: 107-111. doi:10.1017/S0003598X00042307

Banton, S. 2012, Sunrise at and near the winter solstice seen through the gap between Stones 57 and 58. Retrieved 19 February 2016.

URL: http://community.novacaster.com/showarticle.pl?id=11160

Bradley, R. 1989, Darkness and light in the design of megalithic tombs. Oxford Journal of Archaeology, 8: 251-259. doi:10.1111/j1468-0092.1989.tb00205.x

Bradley, R. 2007, The Prehistory of Britain and Ireland. Cambridge University Press, Cambridge, $340 \mathrm{p}$.

Burkert, W. 1985, Greek Religion (English edition). Harvard University Press, Cambridge, Massachusetts, $493 \mathrm{p}$.

Burl, H.A.W. 1994, Stonehenge: Slaughter, sacrifice and sunshine. Wiltshire Archaeological and Natural History Magazine, 87: 85-95.

Camden, W. (translated from Latin by P. Holland) 1610, Britain. Printed by George Bishop and John Norton, London, 25 p.

Campbell, J. 1974, The Mythic Image. Princeton University Press, New Jersey, 552 p.

Campion, N. 2015, Skyscapes as landscapes. In: Skyscapes: The Role and Importance of the Sky in Archaeology (Silva, F. \& Campion, N. Eds.), Oxbow Books, Oxford, 210 p.

Chippindale, C. 1983, Stonehenge Complete. Thames \& Hudson, London, 296 p.

Cleal, R.M.J., Walker, K.E. \& Montague, R. 1995, Stonehenge in its Landscape: Twentieth Century Excavations. English Heritage, London, 618 p.

Cook, A.B. 1940, Zeus: A Study in Ancient Religion. 3. Appendix R. The Hieros Gamos. Digital edition 2010. Cambridge University Press, Cambridge, 366 p.

Cooney, G. 2000, Landscapes of Neolithic Ireland. Routledge, London, 276 p.

Curnow, T. 2004, The Oracles of the Ancient World. Duckworth, London, 242 p.

Darvill, T. 2004, Stonehenge: The Biography of a Landscape. Stroud, Tempus, 319 p.

Darvill, T., \& Wainwright, G. 2009, Stonehenge excavations 2008. The Antiquaries Journal, 89: 1-19. doi:10.1017/S000358150900002X

Das, S. 2014, Unknown Civilization of Prehistoric India. Kaveri Books, New Delhi, 184 p.

Daw, T.C. 2015, The twisted trilithon: Stone 56 and its skew. An investigation into its origin and possible significance. Wiltshire Archaeological and Natural History Magazine. 108: 25-43.

Edmonds, M. 1999, Ancestral Geographies of the Neolithic. Routledge, London, 173 p.

Eliade, M. 1958, (fifth impression 1983), Patterns in Comparative Religion. Sheed and Ward, London, $484 \mathrm{p}$. 
Fowler, C. 2010, Pattern and diversity in the Early Neolithic mortuary practices of Britain and Ireland: Contextualising the treatment of the dead. Documenta Praehistorica. 37: 1-22. doi:10.4312ldp.37.1

Frazer, J.G. 1957, The Golden Bough: A Study in Myth and Religion. MacMillan, London, $756 \mathrm{p}$.

Freeman, G.R., \& Freeman, P.J. 2001, Observational archaeoastronomy at Stonehenge: Winter solstice sunrise and set lines accurate to $0.2 \mathrm{deg}$. in $4000 \mathrm{BP}$. In: Papers at the $33 r$ annual meeting of the Canadian Archaeological Association (Pilon, J.L, Kirby, M.W., \& Thériault, C., Eds.), The Ontario Archaeological Society, Toronto: 200-219 p.

Gibson, A., \& Simpson, D. 1998, Prehistoric Ritual and Religion. Sutton, Stroud, 242 p.

Gimbutas, M. 1989, The Language of the Goddess. Harper and Row, San Francisco, 388 p.

Gimbutas, M. 1991, The Civilization of the Goddess: The World of Old Europe. HarperCollins, San Francisco, 529 p.

Gray, H. St. George 1935, VI. - The Avebury Excavations, 1908-1922. Archaeologia (Second Series), 84: 99-162. doi:10.1017/S0261340900013655

Grinsell, L.V. 1976, Folklore of Ancient Sites in Britain. David and Charles, Newton Abbott, $320 \mathrm{p}$.

Hawley, W. 1921, Stonehenge: Interim Report on the exploration. Antiquaries Journal, 1(1): 19-41. doi:10.1017/S0003581500052975

Hawley, W. 1928, Report on the excavations at Stonehenge during 1925 and 1926. Antiquaries Journal. 8: 149-176. doi:10.1017/S0003581500012063

Hicks, R. 1985, Astronomical traditions of Ancient Ireland and Britain. Archaeoastronomy, 8: 70-79.

John, B. 2011, Bluestone rock types. Retreived 30 January 2016. URL: https://brianmountainman.blogspot.com/2011/12/bluestone-rock-types.html

Kramer, S.N. 1969, The Sacred Marriage Rite: Aspects of faith, myth, and ritual in ancient Sumer. Indiana University Press, Bloomington, $170 \mathrm{p}$.

Krupp, E.C. 1997, Skywatchers, Shamans and Kings. Chapter 4, Mother Earth. Wiley, New York, $364 \mathrm{p}$.

Meaden, G.T. 1992, The Stonehenge Solution. Souvenir Press, London, 224 p.

Meaden, G.T. 1997, Stonehenge: The Secret of the Solstice. Souvenir Press, London, 168 p.

Meaden, G.T. 1999, Secrets of the Avebury Stones. Souvenir Press, London, 152 p.

Meaden G.T. (Ed.) 2012a, Archaeology of Earth Mother Sites and Sanctuaries. British Archaeological Reports Vol. S 2389, Archaeopress, Oxford, 132 p.

Meaden, G.T. 2012b, The Five Megaliths of the Avebury Cove, pp 67-72, In: Archaeology of Earth Mother Sites and Sanctuaries (Meaden, G.T. Ed.), British Archaeological Reports Vol. S 2389, Archaeopress, Oxford, 132 p.

Meaden, G.T. 2017, Drombeg Stone Circle, Ireland, analyzed with respect to sunrises and lithic shadow-casting for the eight traditional agricultural festival dates and further validated by photography. Journal of Lithic Studies, 4(4): 5-37 p.

doi:10.2218/jls.v4i4.1919 
Merrifield, R. 1987, The Archaeology of Ritual and Magic. Batsford, London, 224 p.

Parker Pearson, M., \& Ramilisonina 1998a, Stonehenge for the ancestors: The stones pass on the message, Part 1. Antiquity, 72: 308-326. doi:10.1017/S0003598X00086592

Parker Pearson, M., \& Ramilisonina 1998b, Stonehenge for the ancestors: The stones pass on the message, Part 2. Antiquity, 72: 855-856. doi:10.1017/S0003598X00087470

Pásztor, E., Roslund, C., Juhász, Á., \& Dombi, M. 2000, Simulation of Stonehenge, In: Virtual Reality in Archaeology. (Book + CD-ROM edition) (Barceló, J.A., Forte, M. \& Sanders, D. Eds.). British Archaeological Reports. International Series Vol. 843. Archaeopress, Oxford: p. 111-113. (containing: Pásztor, E., Roslund, C., Juhász, Á., Dombi, M. and Karáth, I. (1998) "Stonehenge: stage for a lightshow?")

Pásztor, E. 2011, The harmony of the immaterial and the material in prehistoric monuments: Investigating ancient light and shadow interaction, In: Experiments with Past Materialities (Gheorghiu, D., \& Children, G., Eds.), British Archaeological Reports. International Series Vol. S 2302, Archaeopress, Oxford: p. 90-109.

Pitts, M.W. 1981, Stones, pits and Stonehenge. Nature. 290: 46-47. doi:10.1038/290046a0

Pitts, M.W. 1982, On the road to Stonehenge: Report on investigations beside the A344 in 1968, 1979 and 1980. Proceedings of the Prehistoric Society, 48: 75-132. doi:10.1017/S0079497X00008392

Prendergast, F.T. 1991, Shadow casting phenomena at Newgrange. Survey Ireland, November 1991: 1-18, (p. 15 for shadow sketches).

Pritchard, O. 2016, Shadows, Stones and Solstices. Journal of Skyscape Archaeology, 2(2): 145-164. doi:10.1558/jsa.29787

Ruggles, C.L.N. 1997, Astronomy and Stonehenge. Proceedings of the British Academy, 92: 203-229.

Silva, F., \& Campion, N. (Eds.) 2015. Skyscapes: The Role and Importance of the Sky in Archaeology. 11 papers. Oxbow Books, Oxford, 210 p.

Smith, I.F. 1965, Windmill Hill and Avebury: Excavations by Alexander Keiller 1925-1939. Oxford University Press, Oxford, 265 p.

Smith, M., \& Brickley, M. 2009, People of the Long Barrows: Life, Death and Burial in the Earlier Neolithic. History Press, Stroud, 192 p.

Snailum, T. 1985 (9 August), Shadow of the Heel Stone witnessed touching the Altar Stone. The Wiltshire Times, p. 16.

Stone, E.H. 1924, The Stones of Stonehenge. Robert Scott, London, 150 p.

Stukeley, W. 1743, Abury: A Temple of the British Druids. Self-published by the author (printed by W. Innys), London, $102 \mathrm{p}$. 